\title{
Farklı Öğrenme Yollarının Kullanıldı̆̆ı Zengin Öğrenme Ortamlarının Matematiksel Muhakeme Becerisine ve Problem Çözmeye Yönelik Tutuma Etkisi
}

\author{
Tamer Kutluca1 $\quad$ Ali Tum²
}

\begin{abstract}
Öz
Type/Tür:

Research/Araştırma

Received/Geliş Tarihi: April 17/

17 Nisan 2020

Accepted/Kabul Tarihi: August

19/19 Ağustos 2020

Page numbers/Sayfa No: $344-370$

Corresponding

Author/Illetişimden Sorumlu

Yazar: tkutluca@dicle.edu.tr

\section{iThenticate}

This paper was checked for plagiarism using iThenticate during the preview process and before publication. / Bu çalışma ön inceleme sürecinde ve yayımlanmadan önce iThenticate yazılımı ile taranmıştır.

\section{Copyright (c) 2021 by}

Cumhuriyet University, Faculty of Education. All rights reserved.

$\mathrm{Bu}$ araştırmanın amacı, farklı öğrenme yolları kullanılarak zenginleştirilen öğrenme ortamında öğrenme tercihlerine göre oluşturulan işbirlikli heterojen öğrenci gruplarıyla gerçekleştirilecek öğretimin matematiksel muhakeme becerisine ve problem çözmeye yönelik tutuma etkisini incelemektir. Çalışma Güneydoğu Anadolu bölgesinde bulunan bir il merkezinden rastgele seçilen bir devlet ortaokulunda okuyan yedinci sınıflar arasında matematik başarısı açısından orta düzeyde ve öğrenme stilleri açısından heterojen dağılım gösteren 23 öğrencinin katılımıyla gerçekleşmiştir. Zenginleştirilen öğrenme ortamlarında kesirler ve tamsayılar konularının öğretimi; teknoloji destekli uygulamalar, eğitsel oyunlar, somut materyaller ve karikatürler kullanılarak, günlük yaşamla ilişkilendirilerek ve işbirlikli heterojen gruplarla yapıcı tartışmalar yapılarak 6 hafta boyunca gerçekleştirilmiştir. Araştırma, nicel araştırma yaklaşımlarından öntest - sontest kontrol grupsuz deneysel desen kullanılarak gerçekleştirilmiştir. Araştırmanın verileri, Matematiksel Muhakeme Testi (MMT)'ne ve Matematik Problemi Çözme Tutum Ölçeği (MPÇTÖ)'ne öntest ve sonteste verdikleri cevaplardan elde edilmiştir. MMT'ye verilen cevaplar Wilcoxon İşaretli Sıralar Testi ve Kruskal Wallis testi ile analiz edilmiştir. Ayrıca MMT'ye ilişkin bazı öğrenci cevapları öntest ve sonteste göre kıyaslanarak yorumlanmıştır. MPÇTÖ'ye verilen cevaplar ise ilişkili örneklemler için t-testi kullanılmıştır. Bu öğrenme ortaminda gerçekleştirilen öğretimin öğrencilerin matematiksel muhakeme becerilerini anlamlı düzeyde geliştirdiği ve matematik problemi çözme tutumlarını anlamlı düzeyde iyileştirdiğini göstermiştir. Bu öğrenme ortamının her öğrenme stilline yönelik matematiksel muhakeme becerisini anlamlı düzeyde geliştirdiği ancak öğrenme stilleri açısından bir muhakeme becerisinin gelişiminde bir farklılaşmanın olmadığı tespit edilmiştir.
\end{abstract}

Anahtar Kelimeler: Farklı öğrenme yolları, zenginleştirilmiş öğrenme, matematiksel muhakeme, problem çözme, tutum

\section{Suggested APA Citation/Önerilen APA Atıf Biçimi:}

Kutluca, T., \& Tum, A. (2021). Farklı öğrenme yollarının kullanıldığı zengin öğrenme ortamlarının matematiksel muhakeme becerisine ve problem çözmeye yönelik tutuma etkisi. Cumhuriyet International Journal of Education, 10(1), 344-370. http:/ / dx.doi.org/10.30703/cije.722191

\footnotetext{
1 Doç.Dr., Dicle Üniversitesi, Z.G. Eğitim Fakültesi, Matematik ve Fen Bilimleri Eğitimi Bölümü, Diyarbakır/Türkiye

Assoc.Prof.Dr., Z.G. Faculty of Education, Departments of Mathematics and Science Education, Diyarbakır/Turkey

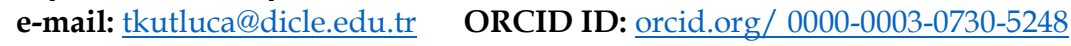

2 Öğretmen, Milli Eğitim Bakanlığı, Adıyaman/Türkiye

Teacher, Ministry of National Education, Adryaman/Turkey

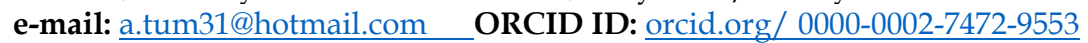




\title{
The Effect of Enriched Learning Environments Using Different Learning Ways on Mathematical Reasoning Skills and Problem Solving Attitude
}

\begin{abstract}
The aim of this research is to investigate the effect of teaching with cooperative heterogeneous groups of students created according to learning preferences in learning environments diversified by different learning methods on mathematical reasoning skills and problem solving attitude. This study was carried out in an official secondary school, determined by random selection from a city center in the Southeastern Anatolia region. In addition, it was applied to 23 students from seventh grade students studying in this school, having a high level of mathematics achievement and having a heterogeneous distribution in terms of learning styles. Teaching of fractions and integers in enhanced learning environments; Constructive analyzes were carried out for 6 weeks (26 lessons in total) using applications that include technology support, educational games, concrete materials and cartoons, establishing relationships with daily life and with the help of cooperative heterogeneous groups. The research was carried out by using an experimental design that is not a pretest-posttest control group, which is one of the quantitative research approaches. The data of the study were obtained with Mathematical Reasoning Test (MRT) and Mathematics Problem Solving Attitude Scale (MPSAC). The answers given to MRT were analyzed with Wilcoxon Signed Sequence Test and Kruskal Wallis test. In addition, the answers of some students obtained by MRT were interpreted according to pretest-posttest. On the other hand, the answers obtained with MPSAC were used for the related samples t-test. The series of analysis show that teaching performed in this learning environment improves students' mathematical reasoning skills significantly and enhances their attitudes towards solving maths problems considerably. In addition, it was concluded that in the learning environment, mathematical reasoning skills for all learning styles were significantly improved, but there was no change in learning styles and the development of reasoning ability.
\end{abstract}

Keywords: Different learning ways, enriched learning, mathematical reasoning, problem solving, attitude

\section{Giriş}

Son yıllarda öğrencilerin zihinsel süreçlerini ortaya koyacak ve bireysel farklılıkları gözetmeksizin her öğrencinin kendine özgü şekilde öğrenme gerçekleştirebilmesi adına çeşitli öğretim metotlarını içerisinde barındıran yaklaşımlar geliştirildiği görülmektedir (Erdem, 2015; Fitriani, Rayid ve Dewanti, 2020). Bu yaklaşımların bireyde tam anlamıyla öğrenme gerçekleşmesi hedefiyle geliştirildiği söylenebilir. Geliştirilecek yaklaşımların bireysel farklılıkları dikkate alarak öğrenciyi merkeze alacak şekilde ortaokul matematik dersi öğretim programında (Milli Eğitim Bakanlığ1 [MEB], 2015; 2018) da ifade edildiği gibi problem çözme sürecinde matematiksel düşünce ve muhakemeleri rahatlıkla ortaya koymasını sağlayacak yöntem ve stratejiler içermesi gereklidir. Çünkü öğrenciyi merkeze alan bu tür yaklaşımların kullanıldığı öğrenme ortamında bilgi statik olmaktan çıkarak dinamik hale gelir. Öğrenci öğrendiği bilgileri kullanarak yeni bilgiler üretebilir. Bu bilgileri karşılaştı̆̆1 problemleri çözmek için kullanırken düşüncelerini ve muhakemesini rahtça ortaya koyabilir. Bu nedenle sınıflarda kullanılacak etkinliklerin, öğrencide bilgiyi ezbere öğretmek yerine bilgiyi keşfetmeye yöneltecek şekilde düzenlenerek uygulanması gereklidir (Novak ve Gowin, 1984). Ayrıca öğrenme ortamlarında farklı yaklaşımların kullanılması zor olarak bilinen derslere karşı motivasyon sağlayarak 
ön yargıları kırmaya yardımcı da olabilir (Özalp, 2006). Farklı öğretim, yöntem ve tekniklerle kavramların öğretilmesi öğrencilere farklı bakış açıları kazanabileceği gibi matematiksel kavram veya konuları anlamakta zorlanan öğrenciler için alternatif yaklaşımları içerisinde barındıracağını gözden kaçırmamak gereklidir.

Okul matematiğinin temel amaçlarından biri bireye günlük hayatında karşılaşacağı problemlerin üstesinden gelmek için temel matematiksel beceriler kazandırmaktır (Fitriana, Musdi ve Anhar, 2018). Bu matematiksel beceriler; problem çözme, muhakemede bulunma, eleştirel ve yaratıcı düşünme gibi üst düzey düşünme becerilerini içerir. Nitekim ilkokul ve ortaokul matematik dersi öğretim programı'nda (MEB, 2018) problem çözme süreçlerinde kendi fikirlerini ve muhakemelerini rahatlıkla belirtebilecek; başkalarının bulunduğu muhakemelerdeki eksiklikleri görebilecek ve matematiksel düşünceyi matematiksel argümanları doğru kullanarak mantıklı bir şekilde açıklayacak ve paylaşacak öğrencilerin yetiştirilmesine yönelik vurgu yapılmıştır. Öte yandan, Kilpatrick, Swafford ve Findell (2001) muhakemenin matematiği bir arada tutan bir rolü olduğuna vurgu yapmıştır. Dolayısıyla öğrencilerin matematiksel muhakemelerini geliştirmek ve kullanmalarını teşvik etmek her matematik derslerinde bir amaç olmalıdır (Bragg, Herbert ve Davidson, 2018). Matematik eğitimi ve öğretimi üzerinde yapılan birçok araştırmada (Erdem, 2015; Erdem ve Gürbüz, 2015; Fischbein ve Schnarch, 1997; Kramarski, Mevarech ve Lieberman, 2001; Lithner, 2008; Polaki, 2002; Umay, 2003) matematik öğrenme sürecinde matematiksel muhakemenin önemli rolünden bahsedilmektedir. Öyle ki bu çalışmalarda muhakeme becerisinin matematik başarısıyla ilişkili olduğu ve daha iyi muhakeme becerisini kullanan bireylerin problem çözmede daha etkili çözümler geliştirerek daha başarılı olduğu ortaya konmuştur.

Literatürde matematiksel muhakemenin gelişimine yönelik tartışma odaklı öğretim, eğitsel oyunlar, teknoloji destekli öğretimler gibi öğretimlerin kullanıldı̆̆ uluslararası birçok çalışmaya rastlamak mümkündür (Ayal, Kusuma, Sabandar ve Dahlan, 2016; Houssart ve Sams, 2008; Kasmer ve Kim, 2011; Kramarski ve Zeichner, 2001; McClain ve Coob, 2001; Mueller ve Yankelewitz, 2014; Olsson; 2018 Pellerin, 2012). Ancak ülkemizde matematiksel muhakemenin geliştirilmesine yönelik üstbilişsel stratejiler yaklaşımına dayalı (Pilten, 2008), argümantasyona (tartışmaya) dayalı öğretimin kullanıldı̆̆1 (Doruk, Duran ve Kaplan, 2018) ve birçok öğretim yöntemini içinde barındıran zenginleştirilmiş öğrenme ortamlarının tasarlanıp ve etkililiği incelendiği (Erdem, 2015; Erdem, Furat ve Gürbüz, 2019; Erdem ve Soylu, 2019) sınırlı sayıda çalışmaya rastlanmıştır. Ayrıca öğrenme stillerinin matematiksel muhakemeyi açıklaması açısından çalışma (Danişman ve Erginer, 2017) yapılmasına rağmen öğrenme stilleri yönünden öğrenme ortamlarının matematiksel muhakeme becerisine etkisinin incelendiği bir çalışmaya rastlanmamıştır.

Öğrenme ortamının çeşitlendirilerek birçok duyu organına hitap etmesi ve öğrenciyi öğrenme etkinliklerinde merkeze alması etkili şekilde öğrenmelerin gerçekleşmesi adına önemlidir. Bu bağlamda, farklı öğrenme stillerini içerisinde barındıran "eğlenceli eğitsel oyunlar", "bilgisayar destekli öğretim uygulamaları", "kavram karikatürleri", "somut materyaller", "günlük yaşamla ilişkilendirme" ve "işbirlikçi tartışma grupları" ve üst düzey açık uçlu soruların öğrenme ortamında kullanılması sayesinde matematiksel kavramların daha etkili öğrenileceği 
düşünülmektedir. Öte yandan kullanılan farklı ve eğlenceli yöntemler sayesinde problem çözmeye yönelik tutumların olumlu yönde gelişeceği düşüncesi vardır. Öğrencilerin matematiksel problem çözmeye yönelik olumlu tutum geliştirilmesine yönelik yapılacak çalışmaların öğrencilerin doğrudan matematiksel muhakeme becerilerini kullanmalarına olumlu şekilde yansıyacağ1 da düşünülmektedir. Dolayısıyla öğrenme stilleri bağlamında zenginleştirilmiş öğrenme ortamlarının matematiksel muhakemeye ve problem çözmeye yönelik tutuma etkisinin incelenmesi hem literatüre hem öğretimin baz alındığı müfredata hem de öğretimi gerçekleştirecek öğretmene katkı sağlaması açısından önemli ve gerekli görülmektedir. $\mathrm{Bu}$ araştırmanın amacı, farklı öğrenme yolları kullanılarak zenginleştirilen öğrenme ortamında öğrenme tercihlerine göre oluşturulan işbirlikli heterojen öğrenci gruplarıyla gerçekleştirilecek öğretimin matematiksel muhakeme becerisine ve problem çözmeye yönelik tutuma etkisini incelemektir. Bu nedenle çalışmada aşağıdaki sorulara cevap aranmıştır:

- Zenginleştirilmiş öğrenme ortamının öğrencilerin matematiksel muhakeme becerilerini geliştirmeye etkisi var mıdır?

- Zenginleştirilmiş öğrenme ortamının öğrencilerin matematiksel muhakeme becerilerini geliştirmede öğrenme stilleri açısından anlamlı bir fark var midir?

- Zenginleştirilmiş öğrenme ortamının öğrencilerin problem çözmeye yönelik tutumlarını iyileştirmeye etkisi var mıdır?

\section{Yöntem}

$\mathrm{Bu}$ çalışma nicel araştırma yaklaşımlarından kontrol grupsuz öntest - sontest deneysel desen benimsenmiştir. Bu çalışmada mevcut durum ile öğrenme süreci sonrasında matematiksel muhakeme becerisinin ve problem çözme tutumunun bu öğrenme ortamında nasıl değiştiğinin amaçlandığından bu araştırma yaklaşımı seçilmiştir.

\section{Çalışma Grubu}

Bu araştırma 2018-2019 eğitim öğretim yılı 2. dönemde Türkiye'de Güneydoğu Anadolu Bölgesinde rastgele seçilen bir devlet ortaokulunda bulunan 23 yedinci sınıf öğrencisiyle gerçekleştirilmiştir. Bu çalışmada çalışma grubu seçilirken rastgele örnekleme ve ölçüt örnekleme yöntemleri kullanılmıştır. Ölçüt örneklemede ve maksimum çeşitlik örneklemesinde rastgele seçilen ortaokuldaki yedinci sınıf öğrencilerinden bir önceki dönem karne not ortalamalarına göre matematik başarı düzeyi orta düzeyde olan ve öğrenme stilleri yönünden maksimum çeşitlilik barındıran heterojen dağılım göstermesi esas alınmıştır.

\section{Veri Toplama Araçları}

Bu çalışmada öğrenme stilleri ölçeği (ÖSÖ), Matematiksel Muhakeme Testi (MMT) ve Matematik Problemi Çözme Tutum Ölçeği (MPÇTÖ) kullanılarak veriler toplanmıştır.

Öğrenme stilleri ölçeği (ÖSÖ). Öğrencilerin öğrenme tercih biçimlerini belirlemek amacıyla kullanılmıştır. Bu ölçek Kolb (2005) tarafından geliştirilen ve Türkçeye uyarlanma çalışması Gencel (2007) tarafından yapılan Kolb öğrenme stilleri envanterinin üçüncü versiyonudur. Bu ölçekte eksik bırakılmış maddelere 
yerleştirilecek şekilde her bir madde somut yaşantı (SY), yansıtıcı gözlem (YG), soyut kavramsallaştırma (SK) ve aktif yaşantı (AY) öğreneme stilleri bileşenlerine ait 4 seçenek olup 12 madde bulunmaktadır Her maddenin seçenekleri için öğrencilerden kendilerine en fazla uygun seçenekten en az uygun seçeneğe doğru 4, 3, 2, 1 şeklinde puanlaması istenmiştir. Bu çalışmada Cronbach Alpha güvenirlik katsayıları SY bileşeni için .75, YG bileşeni için .68, SK bileşeni için .71 ve AY bileşeni için .75 olarak hesaplanmıştır.

Matematiksel muhakeme testi (MMT). Matematik dersi öğretim programında bulunan tamsayılar ve kesirler kazanımlarına yönelik muhakeme gerektiren 24 açık uçlu maddeden oluşan ve güvenirlik katsayısı .86 olan Erdem (2015) tarafından geliştirilen test kullanılmıştır. MMT öntest ve sontest olarak kullanılmıştır. Bu testten alınabilecek en yüksek puan 120 ve en düşük puan 0'dır. Matematiksel muhakeme testinin puanlaması yapılırken Erdem (2011) tarafından geliştirilen 0'dan 5'e kadar puanlama içeren puanlama ölçeği kullanılmıştır. Bu çalışmada Cronbach's Alpha güvenirlik katsayısı öntestte .91, sontestte ise .92 olarak hesaplanmıştır.

Matematik Problemi Çözme Tutum Ölçeği (MPÇTÖ). Araştırmada, öğrencilerinin matematiksel problem çözmeye yönelik tutumlarını belirlemek için Çanakçı (2008) tarafından geliştirilen ve Cronbach's Alpha güvenirlik katsayısı .84 olan 9'u olumlu 10'u olumsuz toplam 19 maddeden oluşan 5'li likert tipi ölçme aracı kullanılmıştır. Bu ölçekten alınabilecek en yüksek puan 95 ve en düşük puan 19 olmaktadır. Bu çalışmadaki Cronbach's Alpha güvenirlik kat sayısı ön testte 79 son teste ise .82 olarak hesaplanmıştır.

\section{Verilerin Analizi}

Araştırmanın verilerini, öğrencilerin ÖSÖ'ye, MMT (Öntest-Sontest)'ne ve MPÇTÖ (Öntest-Sontest)'ne verdikleri cevaplar oluşturmaktadır. Bu veriler, Statistical Package for Social Sciences (SPSS 22) programı kullanılarak analiz edilmiştir. Öğrencilerin öğrenme stilleri belirlenirken SK-SY ve AY-YG birleştirilmiş puanlar hesaplanmıştır. Kolb ve Kolb (2005) tarafından belirtilen şekilde koordinat ekseninde SK-SY " $y$ " eksenine, AY-YG " $x$ " eksenine yerleştirilerek kesişim bölgeleri belirlenerek öğrenme stilleri tespit edilmiştir. MMT’nin puanlaması araştırmacı ve matematik eğitiminde uzman bir akademisyen tarafından bağımsız şekilde ön test ve son test için ayrı ayrı puanlamış ve her iki uygulamada puanlar arası uyumluluk Miles ve Huberman'ın (1994) güvenirlik formülü ile hesaplanmıştır. Ön testteki tutarlılık \%89, son teste ise \% 91 olarak belirlenmiştir. Puanların farklılaştı̆̆ maddelerde iki puanlayıc fikir birliğine varılarak o maddeler yeniden puanlanmıştır. MMT'ye ilişkin analizlerde normal dağılım göstermemesinden dolayı Wilcoxon İşaretli Sıralar Testi ve Kruskal Wallis testi kullanılmıştır. Ayrıca öğrenme ortamının matematiksel muhakemeye etkisini daha iyi incelemek için bazı öğrenci cevapları ön test ve son testte göre kıyaslanarak yorumlanmıştır. MPÇTÖ'ye ilişkin analizde ise normal dağılım göstermesinden dolayı ilişkili örneklemler için t-testi kullanılmıştır.

\section{Süreç}

Bu çalışmada araştırmacı tarafından 6 hafta boyunca toplamda 26 ders saati olmak üzere İlköğretim ve Ortaokul Matematik Dersi 1, 2, 3, 4, 5, 6, 7 ve 8.sinıflar için 
Öğretim Programı (MEB, 2018)'ndaki tamsayılar ve kesirler konularındaki kazanımlara yönelik farklı öğrenme yolları (Teknoloji destekli uygulamalar, Eğitsel oyunlar, Somut materyaller, Karikatürler, Günlük yaşamla ilişkilendirme ve Heterojen işbirlikli öğrenme gruplarıyla yapıcı tartışmalar) kullanılarak gerçekleştirilmiştir. Matematik dersinde en kapsamlı ve diğer matematiksel konuların temelini oluşturması ve günlük yaşamda sürekli kullanılmasından dolayı kesirler ve tamsayılar konuları bu çalışmada ele alınmıştır. Uygulama sürecinde kullanılan her bir öğrenme yoluna ilişkin birer örnek verilerek betimlenmiştir. Her bir öğrenme etkinliğinde araştırmacı rehber ve yönlendirici rol üstlenerek öğrencilerin aktif katılım göstermesine ve işbirlikli gruplarla tartışarak sürecin işlemesine özen göstermiştir.

Teknoloji destekli öğretim uygulamaları Geogebra dinamik matematik ve geometri yazılımı kullanılarak hazırlanmıştır. "Kesirleri tanı, modelle ve karşılaştır", "Kesirlerle çarpma ve bölme işlemini anlamlandıralım", "Köpek Balığı Memo ile Sevimli Kuş ve ASTUM Hastanesinin Asansörleri", "Marsuplamiyi Ailesine Ulaştır" olarak adlandırılmıştır. Aşağıda bu uygulamalardan bir tanesi betimlenmiş ve teknoloji destekli uygulamaların kullanımına ilişkin öğrenme ortamından yansımalar Şekil 1'de verilmiştir.

Kesirleri tanı, modelle ve karşılaştır. Bu uygulama "kesirleri karşılaştırır, sıralar ve sayı doğrusunda gösterir", "tam sayılı kesrin, bir doğal sayı ile bir basit kesrin toplamı olduğunu anlar ve tam sayılı kesri bileşik kesre, bileşik kesri tam sayılı kesre dönüştürür.", "sadeleştirme ve genişletmenin kesrin değerini değiştirmeyeceğini anlar ve bir kesre denk olan kesirler oluşturur" ve "bir çokluğun istenilen basit kesir kadarını ve basit kesir kadarı verilen bir çokluğun tamamını birim kesirlerden yararlanarak hesaplar" kazanımlarının kazandırılmasına yöneliktir. $\mathrm{Bu}$ uygulama ile öğrenciler kesir kavramını anlamlandırabilecek, kesirlerde eş parçalanmanın önemliliğini görebilecek, basit, bileşik ve tam sayılı kesirler oluşturabilecek ve modelle gösterebilecek, sadeleştirme, genişletme ve karşılaştırma yapabilecektir. $\mathrm{Bu}$ uygulama ile öğrenciler kesirlerin nasıl modellendiğini daha düzenli ve görsel olarak görebilecektir. Ayrıca bu modellin belirttiği kesri aynı anda sayı doğrusunda nasıl gösterildiğini anlamlandırabilecektir. Kesirleri uygulamada verilen yönergeler ve öğretmen sorularıla modelleyerek kesirleri karşılaştıracak ve grupça tartışarak karşılaştırmaya yönelik sonuçlar çıkarabileceklerdir.

Öğrenme ortamında kullanılan eğitsel oyunlar, "Dengini Buluyorum ve Eşleştiriyorum", "Çarkı Çevirerek En Fazla Puanı Topla", "Hazine Avcısı" olarak adlandırılmıştır. Bu oyunlarda amaç, öğrencilerin hem hedeflenen kazanımları edinmeleri sağlamak ve pekiştirmek hem de eğlenerek matematik öğrenmelerini sağlamaktır. Tüm oyunlar gruplar arasında oynanmıştır. Her bir oyunu kazanan gruba çeşitli ödüller verilerek, motivasyonları artırılmaya çalışılmıştır. Oyunlarda gruplardaki tüm öğrencilerin katılmalarına dikkat edilmiştir. Öğrencilerin öğretim boyutundan uzaklaşarak tamamen oyuna dalmalarını engellemek için oyun esnasında yapıcı sorular yöneltilmiştir. Aşağıda bu oyunlardan bir tanesi betimlenmiş ve eğitsel oyun kullanımına ilişkin öğrenme ortamından yansımalar Şekil 2 ve Şekil 3'te verilmiştir. 


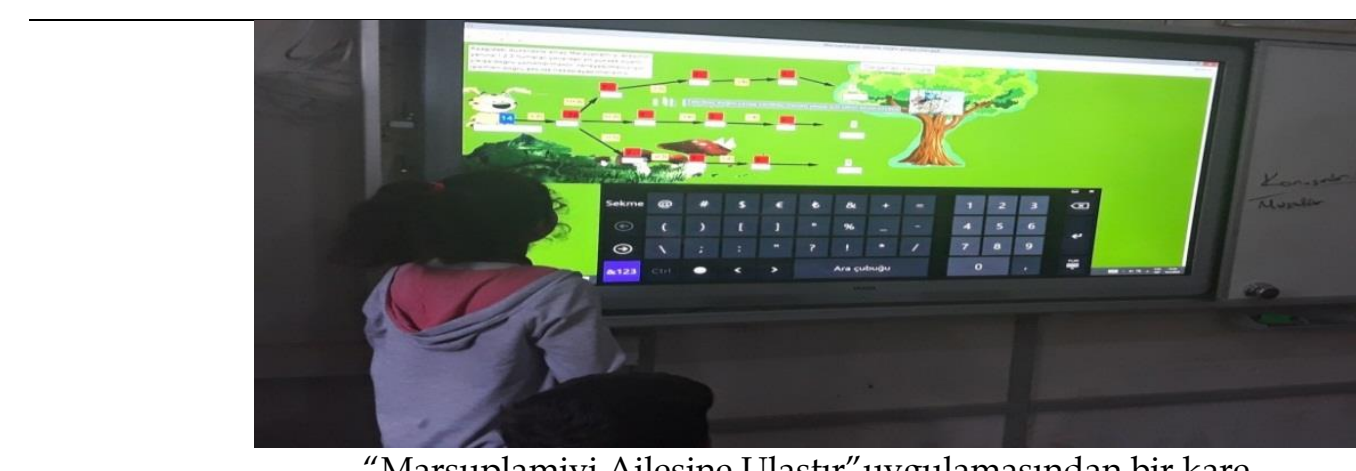

"Marsuplamiyi Ailesine Ulaştır"uygulamasından bir kare

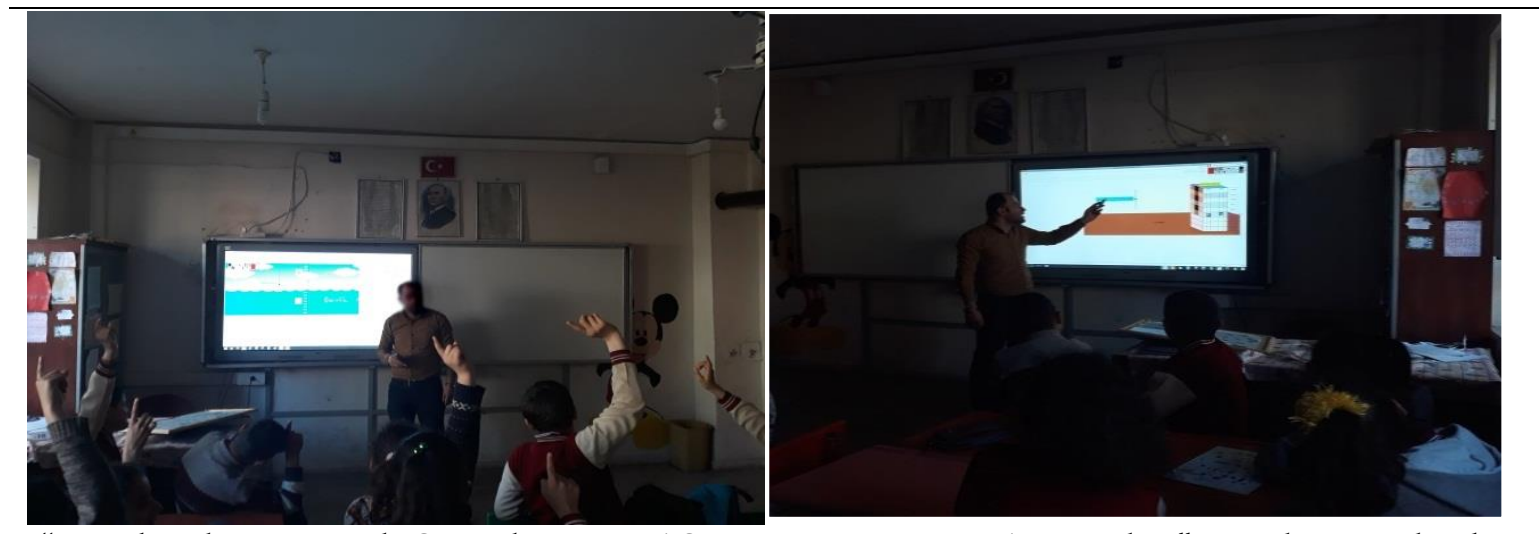

"Köpek Balığı Memo ile Sevimli Kuş ve ASTUM Hastanesinin Asansörleri" uygulamasından bazı kareler
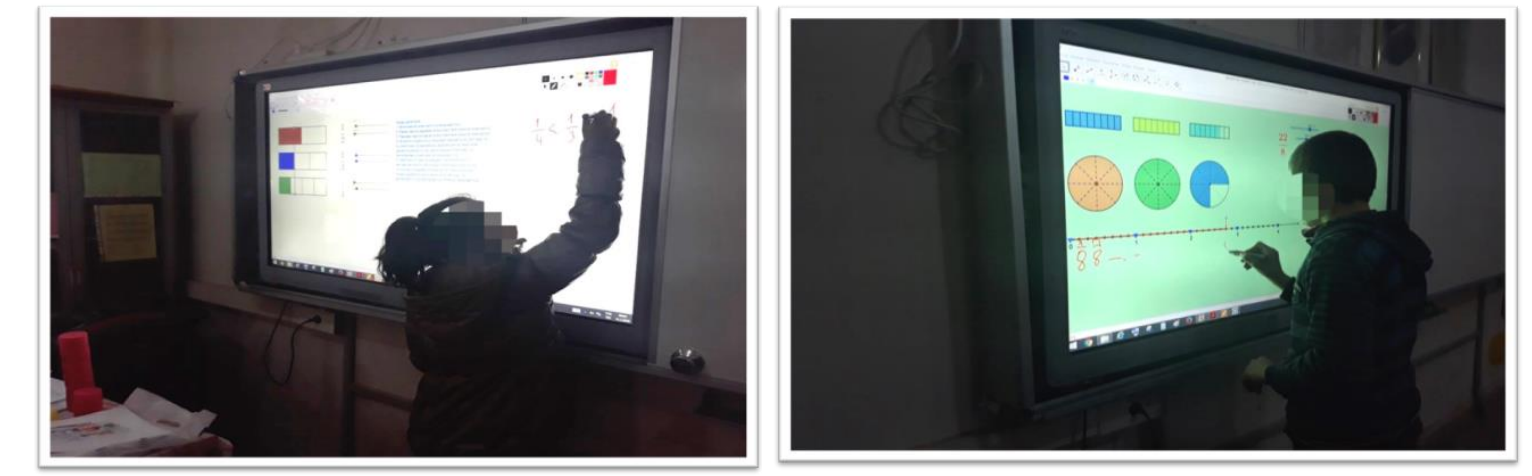

"Kesirleri tanı, modelle ve karşılaştır" uygulamasından bazı kareler
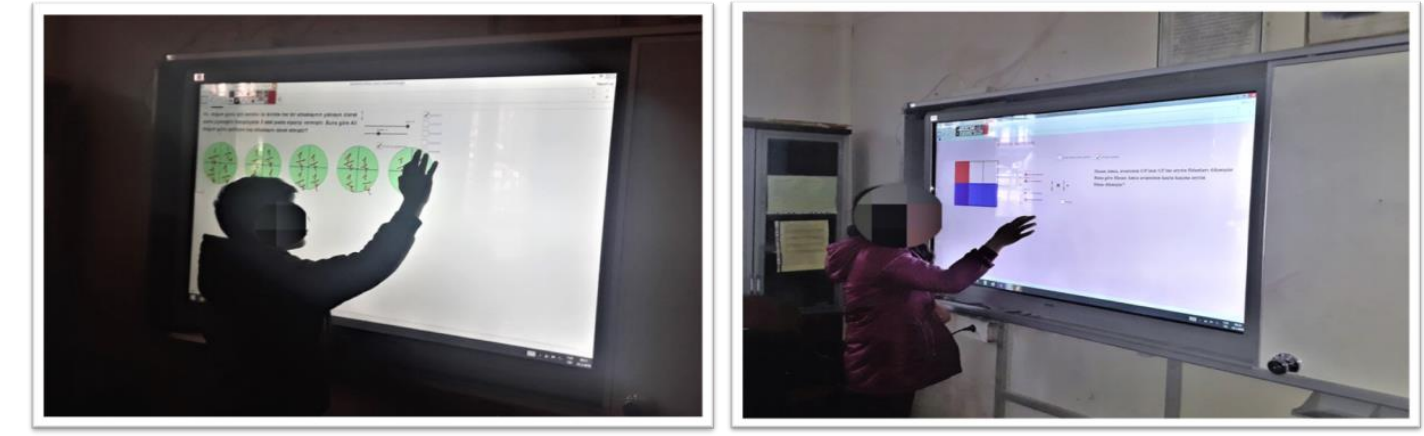

“Kesirlerle çarpma ve bölme işlemini anlamlandıralım" uygulamasından bazı ara yüzlerinin kullanimindan kareler

Şekil 1.Teknoloji destekli uygulamalar

Hazine avcısı. Bu oyun "tam sayılarla toplama ve çıarma işlemlerini yapar; ilgili problemleri çözer" ve "tam sayılarla çarpma ve bölme işlemlerini yapar" kazanımlarına yöneliktir. Bu oyun 11x11 şeklinde kutucuklardan meydana gelen ve bazı kutucukların üzerinde 1 Altın, 2 Altın, 3 Altın ve Sürpriz yazan bir materyal 
kullanilarak 4 grup ile oynanmaktadır. Bu oyunda her grubu temsil eden taşlar kura ile dört başlama noktasına yerleştirilir. Daha sonra sırasıyla öğrenciler her birinin üzerinde kırmızı renkli (Negatif sayıları temsil eden) 1, 2, 3 ve yeşil renkli (pozitif sayıları temsil eden) 1, 2, 3 sayılarının yer aldığ iki zar ile birlikte üzerinde " $X$ " ve "" işaretinin yer aldığı bir pulu havaya atarak zarların üst yüzüne gelen ifadelerle sonuç tam sayı olacak şekilde pulun üst yüzüne gelen simgeyle işlem yapar. Burada " $X$ " ifadesi çarpma veya toplama işlemini " -“ ifadesi ise çıkarma veya bölme işlemini temsil etmektedir. Öğrenci yapacağı işleme karar verir ve araştırmacı kontrolünde işlemi yapar. Elde ettiği sonuç, koordinat sistemindeki eksenlerde yer alan sayısal veriler formatındaki gibi negatif ise sola veya aşağıya doğru, pozitif ise sağa veya yukarı doğru hareket ettirilir. Üzerinde altın yazılı olan kutucuklara gelindiğinde belirtilen kadar altın grubuna kazandırmış olur. Sürpriz kutucuklarına gelindiğinde ise tek zar öğrenci tarafından atılır ve üst yüze pozitif sayı gelmiş ise sayı kadar grubuna altın kazandırır. Eğer negatif sayı gelmişse de sayı kadar altın kasaya iade edilir. Bu oyunla, öğrenci sonuç tam sayı olacak şekilde ve taşının konumuna göre mantıklı kararı vererek işlem yapmalıdır. Her gruptaki öğrenciler zar ve pul atma işlemini yaptıktan sonra elinde en fazla altın olan grup oyunu kazanacaktır. Öğrenciler bu oyunla tam sayılarla dört işlem yapmayı pekiştirecek ve eğlenceli şekilde matematik öğrenerek muhakemelerini kullanarak bu beceriyi geliştirebilecektir.
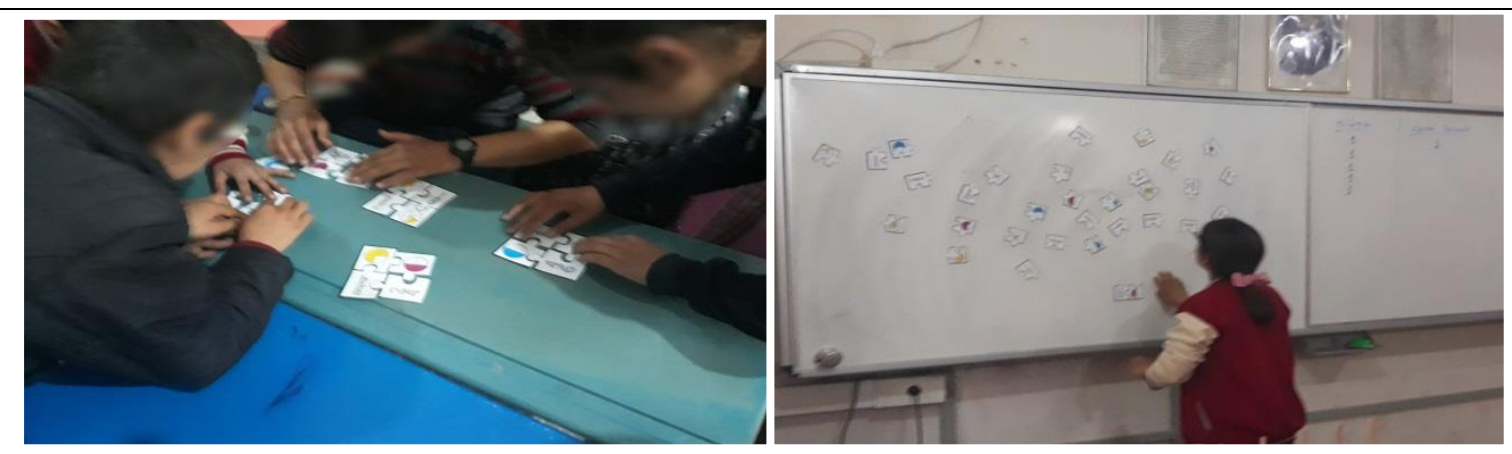

"Dengini Buluyorum ve Eşleştiriyorum" oyunundan kareler

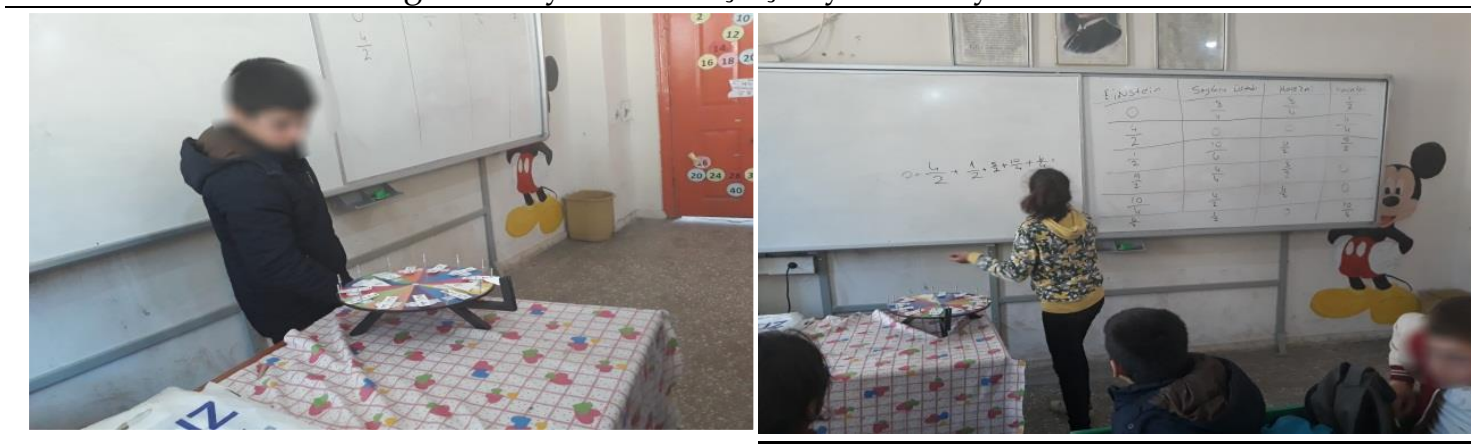

"Çarkı Çevirerek En Fazla Puanı Topla" oyunundan bazı kareler

Şekil 2. Eğitsel oyunların kullanımı 


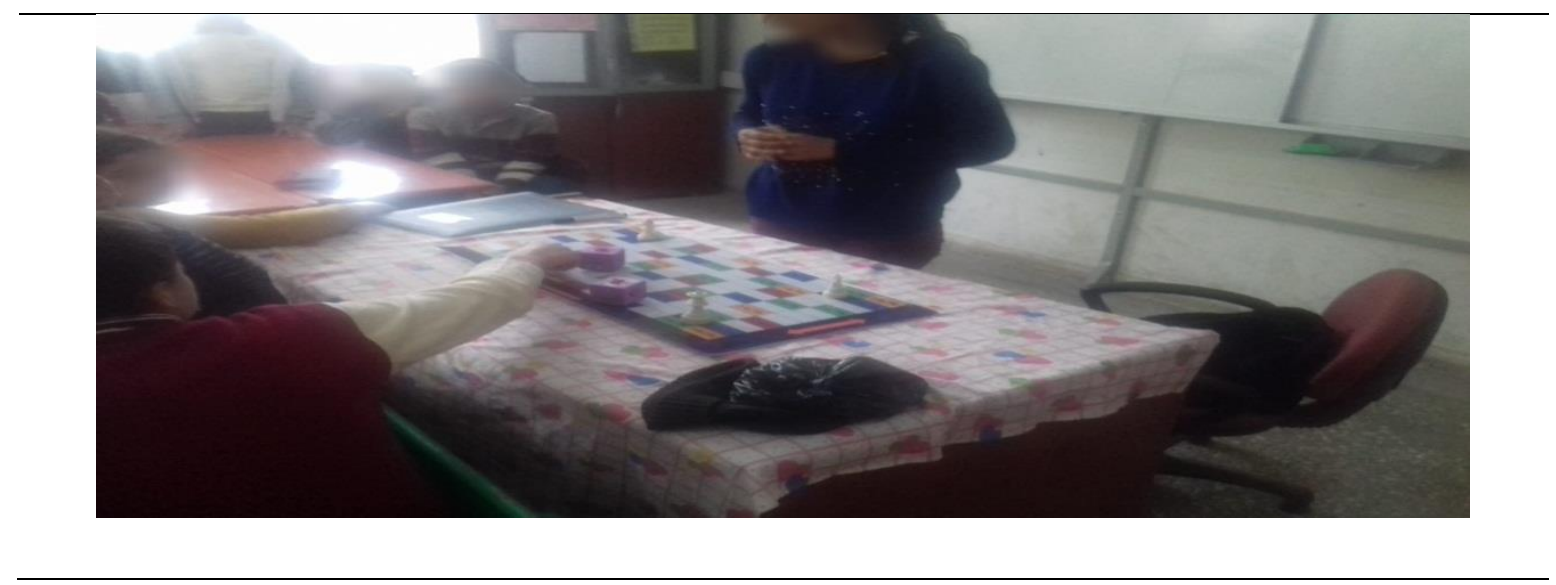

Şekil 3. "Hazine Avcısı" oyunundan bir kare

$\mathrm{Bu}$ öğrenme ortamında öğrencilerin kesirlerle ve tamsayılarla ilgili kazanımları edinmeleri için farklı materyaller kullanılmıştır. Bu somut materyallerin bazıları işbirlikli gruplar arasında oyun etkinliklerinde bazıları kavramların ve karamlar arasındaki ilişkilerin öğretilmesinde kullanılmıştır. Kavramların ve kavramlar arasındaki ilişkileri göstermek amacıyla Inspiration 9E programı kullanılarak tam sayılar ve kesirlere yönelik kavram haritaları hazırlanarak büyük poster şekilde basılmıştır. Ayrıca bu kavram haritaları kuşe kağıda basılarak öğrencilerin incelemeleri sağlanmıştır. Somut materyallerin, öğrencilerin hem dikkatini çeken görsel bir yapıda olması hem de öğrenciler tarafından aktif şekilde kullanılması öğrenmelerin etkili şekilde gerçekleşmesine olanak sağlar. Ayrıca bu öğrenme ortamında Erdem (2015) tarafından tamsayılar ve kesirler konusunda yönelik hazırlanan karikatürler de kullanılmıştır. Her bir karikatür renkli şekilde kuşe kâğıda basılmış şekilde öğrencilere dağıtılarak işbirlikli gruplarda öğrencilerin incelemeleri sağlanarak üzerinde yapıcı tartışmalar yapmaları sağlanmıştır. Ardından bu süreci akıllı tahtada yansıtılarak daha detaylı şekilde öğrenmeleri sağlamak amacıyla öğretmenin anlatımıyla izlemiştir. Bazı somut materyallerin ve karikatürlerin öğrenme ortamında kullanımına ilişkin kareler Şekil 4'te verilmiştir.

$\mathrm{Bu}$ öğrenme ortamında gerçekleştirilen bütün öğrenme etkinlikleri günlük yaşamla ilişkilendirilerek gerçekleştirilmiştir. Bunun dişında tam sayılar konusuna yönelik kavramların günlük yaşamdaki yerlerine ilişkin örnekler verilerek çalışma kâğıtları hazırlanmıştır. Bu örneklerde, öğrencilerin sıklıkla karşılaştıkları binalardaki zemin kat 0 ile zeminin üstündeki katlar pozitif tam sayılarla ve zeminin altındaki katlar negatif tamsayılarla ilişkilendirilebilir. Ayrıca banka hesaplarındaki para girdisi-çıktısı, yükseklik-derinlik, sıcaklık göstergeleri, borç-alacak durumu gibi günlük yaşamda öğrencinin sürekli karşı karşıya gelebileceği olaylarla da ilişkilendirilme yapılmıştır. Öğrencilerin gündelik yaşamın içinde her zaman karşılaşabilecekleri kendisine tanıdık bu durumları kavramlarla ilişkilendirmek anlamlar yüklemesine daha faydalı olacaktır. 


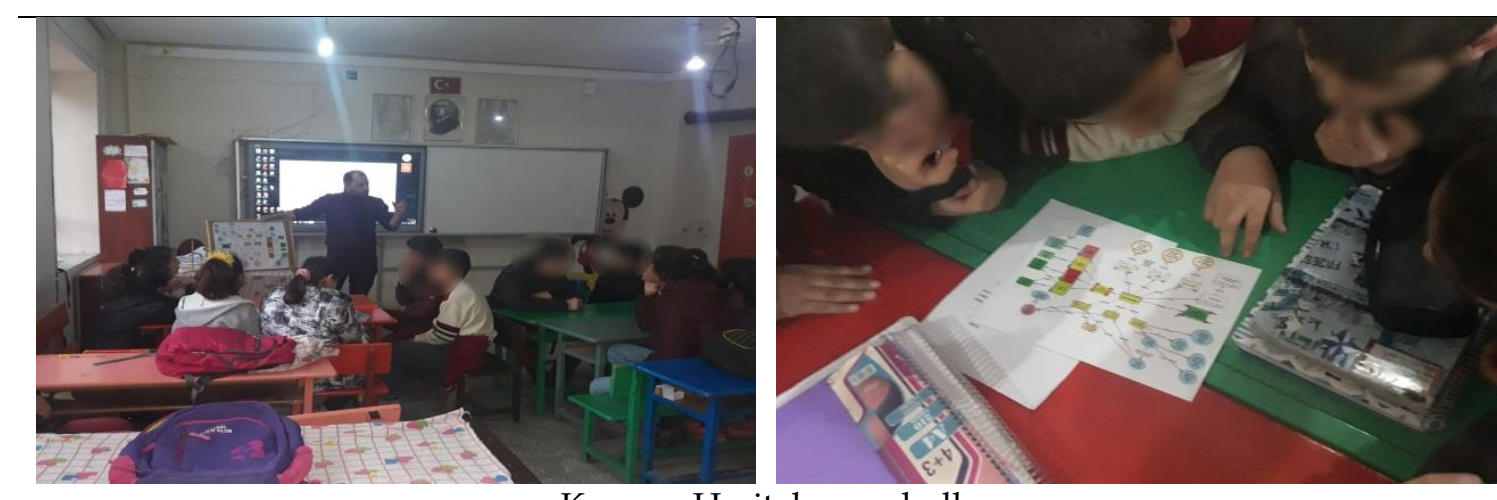

Kavram Haritalarının kullanımı

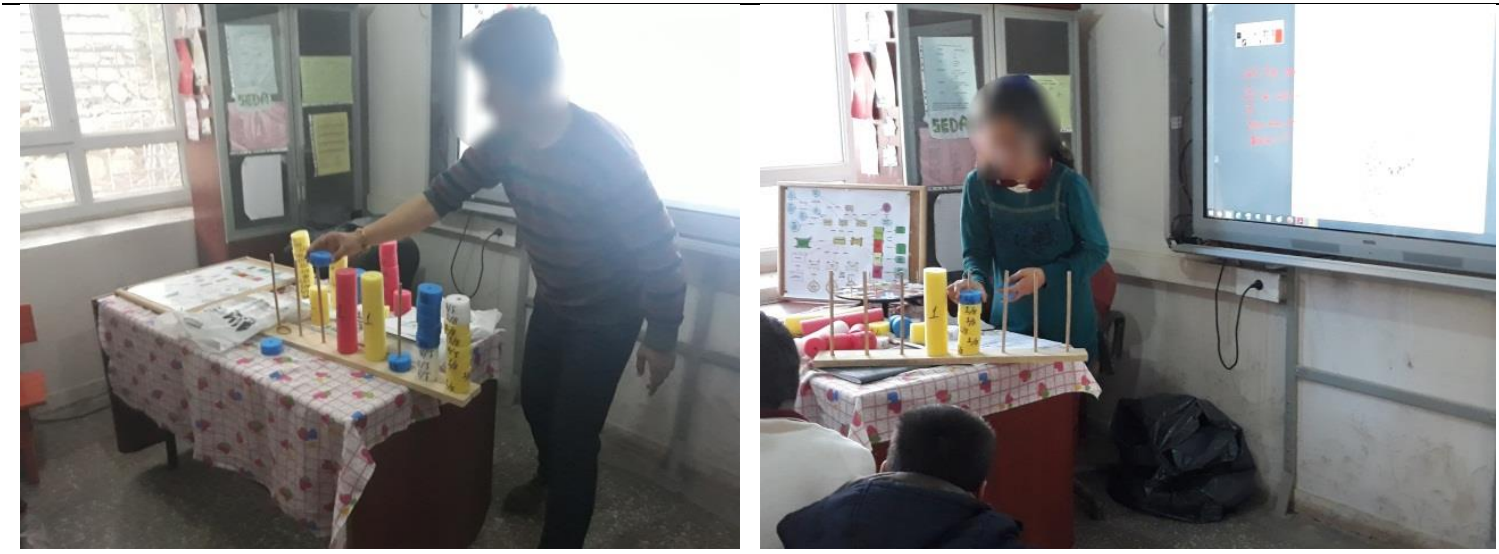

Kesir Abaküsü Materyallinin kullanımı

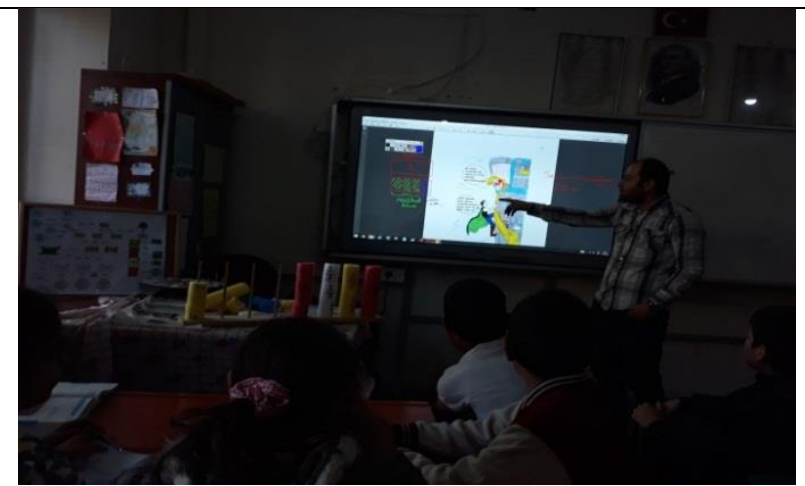

Kavram karikatürlerinin kullanımı

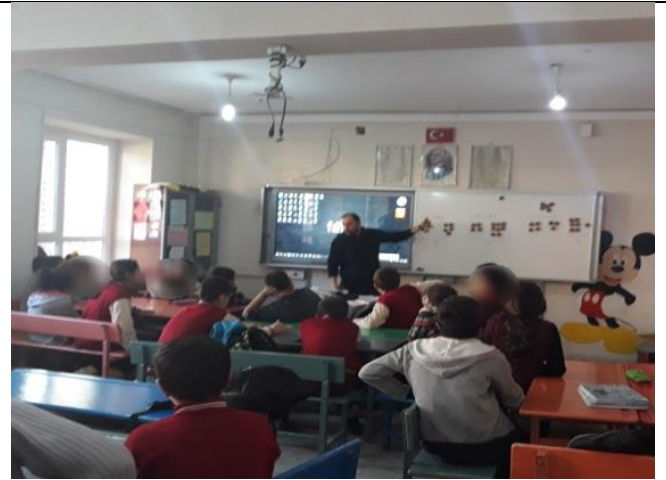

Ahşap Mıknatıslı Sayma Pullarının Kullanımı

Şekil 4. Somut materyal ve karikatür kullanımından kareler

Bu öğrenme ortamında süreç boyunca öğrencilerin araştırmacı rehberliğinde heterojen işbirlikli gruplar halinde yapıcı tartışmalar yapmaları sağlanarak hem birbirlerinden hem de araştırmacıdan öğrenme gerçekleştirmeleri sağlanmıştır. Ayrıca araştırmacı tarafından hazırlanan tamsayılar ve kesirler kazanımlarına yönelik çözümüne hemen ulaşılmayan, üzerinde düşünmeleri ve muhakeme becerilerini kullanabilecekleri açık uçlu problemler grupça çözdürülmüş ardından araştırmacı tarafından detaylıca farklı yöntem ve stratejiler kullanılarak öğrencilere anlatılmıştır. Aşağıda bu öğrenme ortamında kullanılan açık uçlu bir problem Şekil 5 'te verilmiştir. 


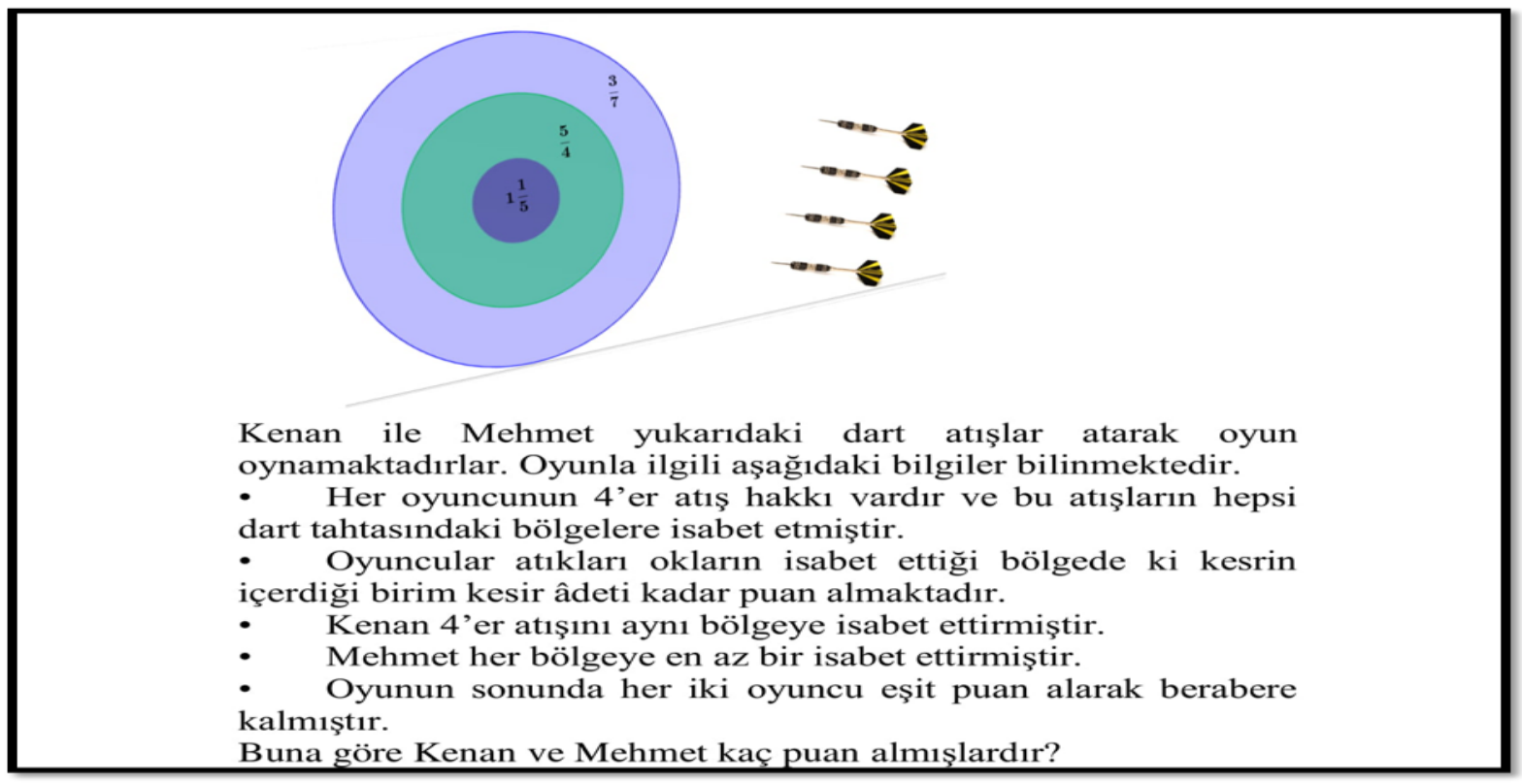

Şekil 5. Kesirler konusuna yönelik kullanılan bir açık uçlu problem örneği

\section{Araştırmanın Etik İzinleri}

Yapılan bu çalışmada "Yükseköğretim Kurumları Bilimsel Araştırma ve Yayın Etiği Yönergesi" kapsamında uyulması belirtilen tüm kurallara uyulmuştur. Yönergenin ikinci bölümü olan "Bilimsel Araştırma ve Yayın Etiğine Aykırı Eylemler" başlı̆̆ı altında belirtilen eylemlerden hiçbiri gerçekleştirilmemiştir.

Etik kurul izin bilgileri

Etik değerlendirmeyi yapan kurul adı = Dicle Üniversitesi Eğitim Bilimleri Etik Kurulu

Etik değerlendirme kararının tarihi $=21$ Ocak 2019

Etik değerlendirme belgesi sayı numarası= KARAR 2019/1-6

\section{Bulgular}

Zenginleştirilmiş öğrenme ortamının öğrencilerin matematiksel muhakeme becerilerini geliştirmeye etkisinin olup olmadığını belirlemek amacıyla MMT (öntestsontest)'ne yönelik Wilcoxon İşaretli Sıralar Testi yapılmış ve elde edilen bulgular Tablo 1'de gösterilmiştir.

Tablo 1

MMT'ye İlişkin Wilcoxon İşaretli Sıralar Testi Sonuçları

\begin{tabular}{cccccc}
\hline $\begin{array}{c}\text { Öntest- } \\
\text { Sontest }\end{array}$ & $\mathrm{n}$ & $\begin{array}{c}\text { Sıra } \\
\text { Ortalamas }\end{array}$ & Sira Toplamı & $\mathrm{z}$ & $\mathrm{p}$ \\
\hline Negatif Sıra & 0 & .00 & .00 & & \\
Pozitif Sıra & 23 & 12.00 & 276.00 & -4.19 & .00 \\
Eşit & 0 & - & - & & \\
\hline
\end{tabular}

Tablo 1'de görüldüğü gibi, analiz sonuçları öğrencilerin $\mathrm{MMT}^{\prime}$ den aldıkları ön test ve son test puanları arasında anlamlı bir fark olduğunu göstermektedir $(z=-4.19$, $\mathrm{p}<.05)$. Fark puanlarının sıra ortalaması ve toplamları dikkate alındığında, gözlenen farkın pozitif sıralar, yani son test puanı lehinde olduğu görülmektedir. Bir başka 
ifadeyle, öğrencilerin $\mathrm{MMT}^{\prime}$ ye ilişkin son test puanlarının ön test puanlarına göre anlamlı düzeyde daha yüksek olduğu belirlenmiştir. MMT'de yer alan soruların muhakeme becerilerini ölçtüğü düşünüldüğünde, bu öğrenme ortamının öğrencilerin matematiksel muhakemelerini geliştirmede önemli bir etkisinin olduğu söylenebilir. Öyle ki tüm cevap kâğıtları incelendiğinde, her öğrencide farklı düzeyde olsa da öğrencilerin muhakeme testinden aldıkları Sontest puan ortalamaları Öntest puan ortalamalarından daha yüksek olduğu belirlenmiştir. Matematiksel muhakemeye etkisini daha iyi ortaya koyabilmek için bazı öğrencilerin MMT'deki bazı sorulara öntest ve sontestte verilen cevaplar karşılaştırıldı̆̆ında öğrencilerin son testte göstermiş oldukları performanslar ön testte göre daha başarılı olduğu görülmektedir. Aşağıda bazı öğrencilerin bazı sorulara ön test ve son testte verdikleri cevaplar karşılaştırılıp yorumlanmıştır.

Merve. 24 tane Türkçe, 16 tane matematik, 12 tane fen ve teknoloji sorusunun yer aldığı, bir deneme sınavma girmiştir. 16 tane Türkçe, 14 tane matematik, 10 tane fen ve teknoloji sorusunu doğru cevapladı̃̆ına görc. Merve nin hangi d̦erste daha başarılı olduğunu bularak açıklayınız.

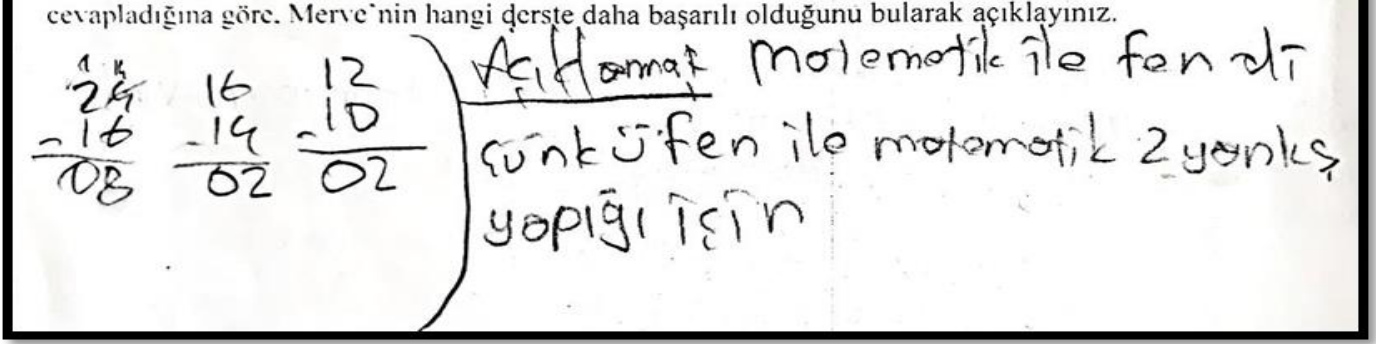

Şekil 6. Ö1 öğrencisinin öntestte MMT’deki ikinci soruya verdiği cevap

Merve, 24 tane Türkçe, 16 tane matematik, 12 tane fen ve teknoloji sorusunun yer aldığı, bir deneme sinavina girmiştir. 16 tane Türkçe, 14 tane matematik, 10 tane fen ve teknoloji sorusunu doğru cevapladığına göre, Merve'nin hangi derste daha başarılı olduğunu bularak açıklayınız.

$$
\begin{aligned}
& 25-16=8 \text { yonlis, furkse } \\
& 16-4=2 \text { yonlis moremotik } \\
& 12-10=2 \text { yonlis Fen }
\end{aligned}
$$

Şekil 7. Ö1 Öğrencisinin sontestte MMT'deki ikinci soruya verdiği cevap

MMT'deki ikinci soruda öğrenciler şu şekilde muhakemede bulunmaları beklenmektedir: Öncelikle her bir dersin başarı oranı karşılaştırılacaktır. Bunun için her bir dersin doğru sayısının tüm sorulara oranını gösteren kesirli ifadelerin karşılaştırılması gerekmektedir. Karşılaştırma yapmayı düşünmek tek başına matematiksel muhakemenin kullanımının göstergesi olarak ifade edilebilir. Bu karşılaştırma işlem payda eşitleme, modelle gösterme gibi birçok farklı yöntemle yapılabilir. Şekil 6'da bu soruya Ö1 öğrencisi her ders için tüm sorulardan doğru soru sayısını çıkartarak yanlış sayılarını bulmuş ve yanlış sayıları üzerinden başarılı olan dersleri kıyaslamıştır. Ancak öğrenci her derste eşit soru sorulmadığını düşünemeyerek yanlış muhakemede bulunmuştur. Ancak Şekil 7'de sontestte bu soruya yanlış yapılan soru sayısını bulduktan sonra az sayıda eşit yanlış yapılan 
Matematik ve Fen ve Teknoloji derslerinden doğru sayısı ve sorulan soru sayısı fazla olanın daha başarılı olduğunu ifade ederek en başarılı dersin matematik olduğunu belirtmiştir. Burada öğrenci kısmen de olsa doğru cevap ve açıllama yaparak önteste göre daha iyi muhakemede bulunmuştur. Nitekim Ö1 öğrencisinin ön test MMT puan ortalaması 1.54 olarak hesaplanmıştır. Bu ortalama "düşük" düzey aralığına düşmektedir. Sontest MMT puan ortalaması ise 2.29 olarak hesaplanmış ve bu ortalama "orta" düzey aralığına düşmektedir. Tüm bu değerlendirmeler sonucunda, yapılan öğretimin sonucu olarak Ö1 öğrencisinin muhakeme becerisinin iyileştiği söylenebilir.

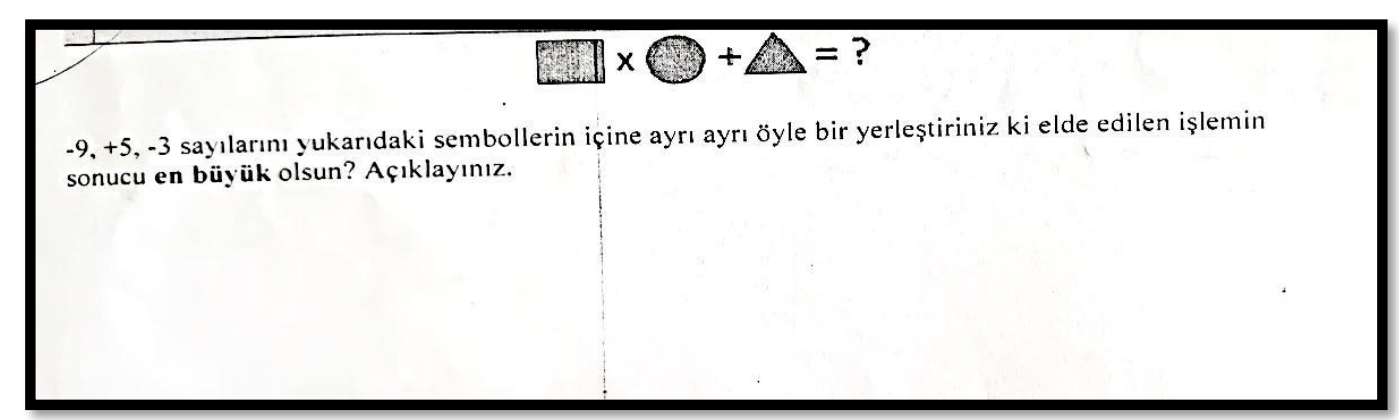

Şekil 8. Ö10 öğrencisinin öntestte MMT'de 19.soruya verdiği cevap

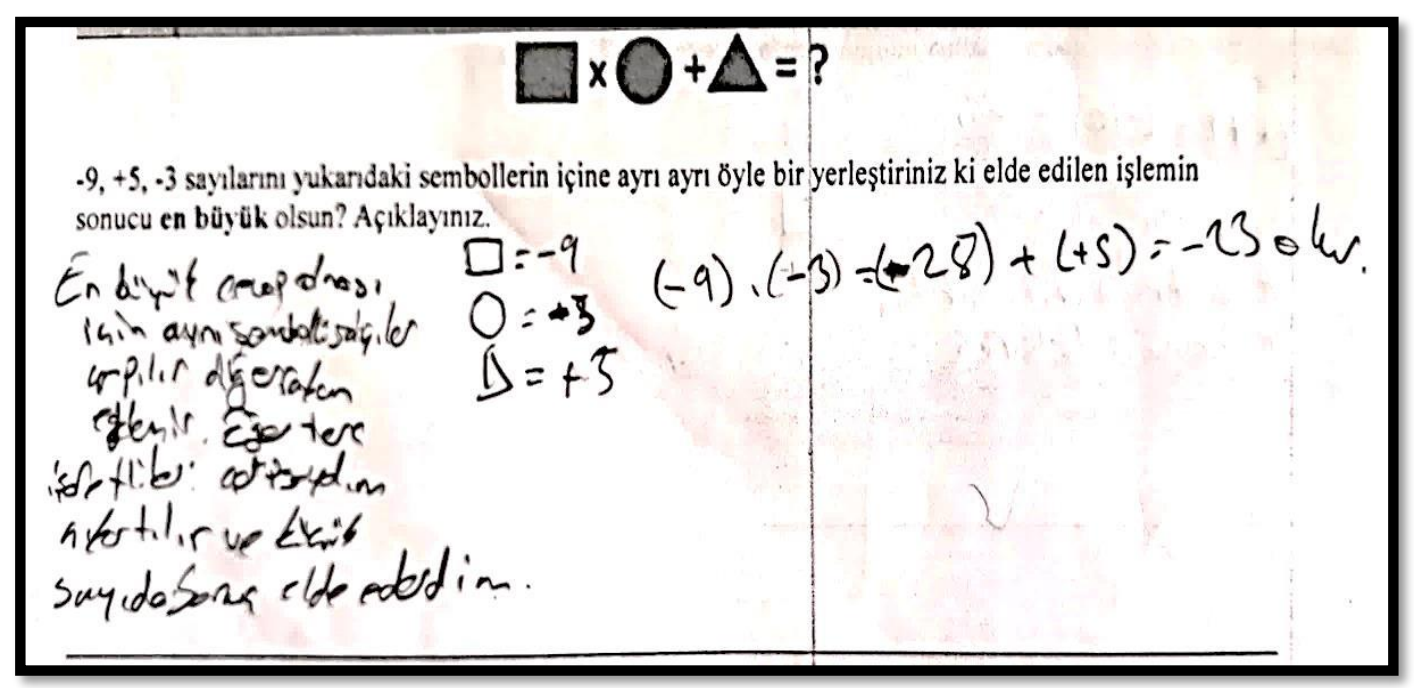

Şekil 9. Ö10 öğrencisinin sontestte MTT’de 19.soruya verdiği cevap

MMT'deki 19. soruda öğrenciler şu şekilde muhakemede bulunmaları beklenmektedir: $-9,+5$ ve -3 sayılarını sembollere yerleştirirken işlemin sonucunun en büyük olabilmesi için çarpılacak sembollere negatif tam sayılar verilmelidir. Çünkü iki negatif tam sayının çarpımının pozitif bir tam sayı olacaktır. Ayrıca bazı ihtimalleri de göz önüne almalıdır. Şekil 8'de Ö10 öğrencisi öntestte bu soruya cevap vermezken Şekil 9' da sontestte beklenen şekilde muhakeme gerçekleştirdiği yalnız tek ihtimali düşündüğü görülmektedir. Ayrıca yapmış olduğu çarpma işleminde yanlışlık yaptığı da görülmektedir. Ö10 öğrencisinin MTT ön test puan ortalaması 1.96 (Düşük düzey) iken son test puan ortalaması 2.58 (Orta düzey) olarak hesaplanmıştır. Bu değerlendirmeler 1şı̆̆ında Ö10 öğrencisinin matematiksel muhakeme becerisinin iyileştiği söylenebilir. 
yunun dibinde bulunan bir kurbağa 1 dakika sonunda 3 metre yukarıy 10 metre derinliģindeki bir kuyunun

sictis

$$
\begin{aligned}
& 10 \mathrm{~m} \text { derinlik }=-10 \text { 1dakibada }(+3)+(-2)=+1 \text { 1dakikada imetre } \\
& \text { ciktigina göre } 101 \mathrm{k} \mathrm{kada.} \mathrm{10metre} \mathrm{cildar}
\end{aligned}
$$

Şekil 10. Ö17 öğrencisinin öntestte MTT'de 13.soruya verdiği cevap

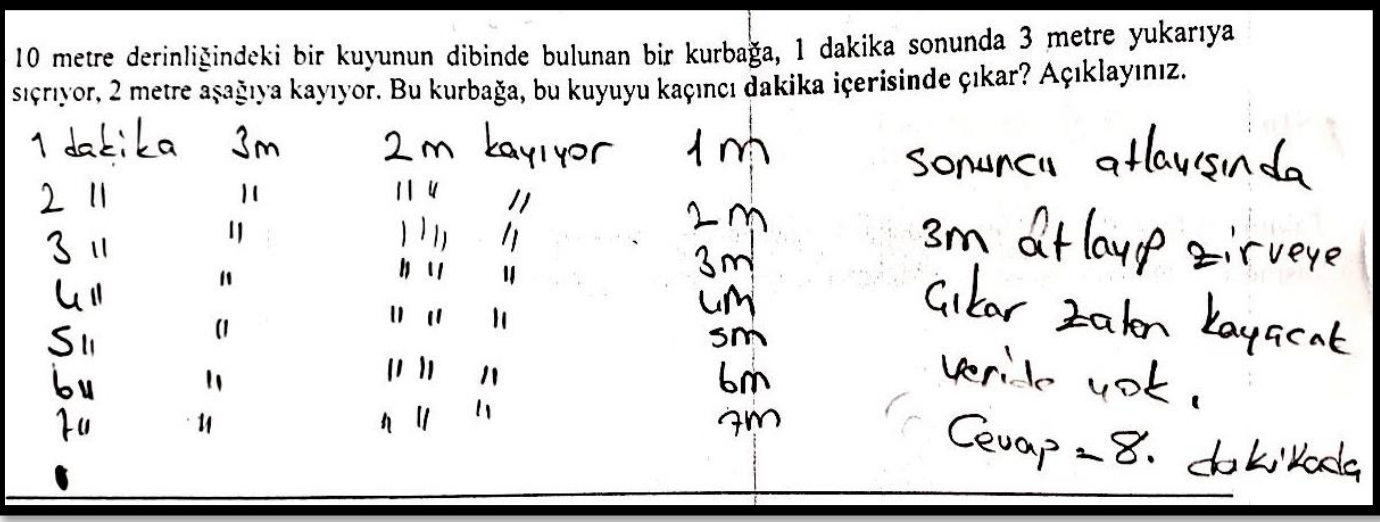

Şekil 11. Ö17 öğrencisinin sontestte MTT'de 13.soruya verdiği cevap

MMT'deki 13.soruda öğrencilerin şu şekilde muhakemede bulunmaları beklenmektedir: Öncelikle kurbağanın 1 dakika boyunca 3 metre yukarı 2 metre aşağı harekettin de toplamda 5 metrede 1 metre yukarı hareket edecektir. Ayrıca kurbağa bu şekilde hareket ettiğinde 7.dakikada 7 metre yukarı çıkacaktır ve 8 . dakika içerisinde 3 metre daha yukarı sıçradığında kuyudan çıkmış olacaktır. Şekil 10 'da Ö17 öğrencisi öntestte 13. soruda kurbağanın 1 dakikada toplamda 1 metre yukarı çıkabildiğini düşünmesine rağmen doğru orantılı düşünerek 10 metreyi 10 dakikada çıkabileceğini belirtmiştir. Şekil 11'de sontestte 13 . soruya beklenen muhakemeyi tamamıla göstermiş ve sistematik şekilde her dakikada ne kadar mesafe alındığını belirtmiştir. Ardından 7. dakikada 7 metre çıktıktan sonra 8.dakikada 3 metre daha yukarı çıkarak kuyudan çıktığını ifade etmiştir. Ö17 öğrencisinin MMT öntestte ve sontestte 13. soruya verdiği cevaplar karşılaştırıldığında muhakemesinin geliştiğini söyleyebiliriz. Nitekim Ö17 öğrencisinin ön test MMT puan ortalaması 2.58 ve son test MMT puan ortalaması 3.50 olarak hesaplanmıştır. Bir başka deyişle Ö17 öğrencisinin matematiksel muhakeme beceri düzeyi ön testte Orta düzeydeyken son teste yüksek düzeye çıkmıştır. Bütün bunlardan hareketle Ö17 öğrencisinin matematiksel muhakeme becerisinin bu öğretimler sonucunda geliştiği söylenebilir. Benzer şekilde diğer bütün öğrencilerin öntestte ve sontestte MMT'deki cevapları kıyaslandı̆̆ında oluşturulan öğretim ortamının farklı oranlarda da olsa her öğrencinin matematiksel muhakeme becerisine katkısı olduğu ve geliştirdiği söylenebilir. 
Zenginleştirilmiş öğrenme ortamının öğrencilerin matematiksel muhakeme becerilerini geliştirmede öğrenme stilleri açısından anlamlı bir fark olup olmadığını belirlemek maksadıyla Wilcoxon İşaretli Sıralar testi yapılmış ve bu analize ilişkin sonuçlar Tablo 2'de gösterilmiştir. Ayrıca, öğrenme stilleri gruplarının MMT'ye ilişkin ön test puanlarının ve son test puanlarının anlamlı düzeyde bir farklılık olup olmadığını incelemek için Kruskal Wallis H- testi yapılmış ve sonuçlar Tablo 3'te verilmiştir.

Tablo 2

Öğrenme Stilleri Bağlamında MMT'ye İlişkin Öntest- Sontest Wilcoxon İşaretli Stralar Testi Sonuçlan

\begin{tabular}{|c|c|c|c|c|c|c|}
\hline $\begin{array}{c}\text { Öğrenme } \\
\text { stili }\end{array}$ & $\begin{array}{c}\text { Sontest- } \\
\text { Öntest }\end{array}$ & $\mathbf{n}$ & $\begin{array}{c}\text { Sira } \\
\text { Ortalamas1 }\end{array}$ & Sira Toplamı & $\mathbf{z}$ & $p$ \\
\hline \multirow{3}{*}{ Değiştiren } & Pozitif Sıra & 6 & 3.50 & 21.00 & \multirow{3}{*}{-2.20} & \multirow{3}{*}{.028} \\
\hline & Negatif Sira & 0 & .00 & .00 & & \\
\hline & Eşit & 0 & - & - & & \\
\hline \multirow{3}{*}{ Özümseyen } & Pozitif Sira & 5 & 3.00 & 15.00 & \multirow{3}{*}{-2.02} & \multirow{3}{*}{.043} \\
\hline & Negatif Sıra & 0 & .00 & .00 & & \\
\hline & Eşit & 0 & - & - & & \\
\hline \multirow{3}{*}{ Ayrıştıran } & Pozitif Sira & 5 & 3.00 & 15.00 & \multirow{3}{*}{-2.02} & \multirow{3}{*}{.043} \\
\hline & Negatif Sıra & 0 & .00 & .00 & & \\
\hline & Eşit & 0 & - & - & & \\
\hline \multirow{3}{*}{ Yerleştiren } & Pozitif Sıra & 7 & 4.00 & 28.00 & \multirow{3}{*}{-2.36} & \multirow{3}{*}{.018} \\
\hline & Negatif Sira & 0 & .00 & .00 & & \\
\hline & Eşit & 0 & - & - & & \\
\hline
\end{tabular}

Tablo 2'deki sonuçlar incelendiğinde her dört öğrenme stilli gruplarına göre öğrencilerin matematiksel muhakeme becerilerini bu öğrenme ortamı anlamlı bir şekilde geliştirdiği söylenebilir $(\mathrm{z}=-2.20, p<.05 ; \mathrm{z}=-2.02, p<.05 ; \mathrm{z}=-2.02, p<$ $.05 ; \mathrm{z}=-2.36, p<.05)$.

Tablo 3

MMT'ye ilişkin öntest ve sontest ölçümlerinin öğrenme stillerine yönelik Kruskal Wallis Testi Sonuçları

\begin{tabular}{|c|c|c|c|c|c|c|}
\hline Ölçüm & $\begin{array}{l}\text { Öğrenme } \\
\text { stili }\end{array}$ & $\mathbf{n}$ & $\begin{array}{c}\text { Sira } \\
\text { ortalamas1 }\end{array}$ & sd & $\chi^{2}$ & $p$ \\
\hline \multirow{4}{*}{ Öntest } & Değiştiren & 6 & 6.42 & \multirow{4}{*}{3} & \multirow{4}{*}{6.90} & \multirow{4}{*}{.075} \\
\hline & Özümseyen & 5 & 11.60 & & & \\
\hline & Ayriştıran & 5 & 13.30 & & & \\
\hline & Yerleştiren & 7 & 16.14 & & & \\
\hline \multirow{4}{*}{ Sontest } & Değiştiren & 6 & 7.17 & \multirow{4}{*}{3} & \multirow{4}{*}{4.97} & \multirow{4}{*}{.174} \\
\hline & Özümseyen & 5 & 12.20 & & & \\
\hline & Ayriştıran & 5 & 12.70 & & & \\
\hline & Yerleştiren & 7 & 15.50 & & & \\
\hline
\end{tabular}

Tablo 3 incelendiğinde öğrenme stilleri grupları arasında deneysel işlem öncesinde herhangi bir anlamlı fark olmadığ tespit edilmiştir $\left[\chi^{2}(3,23=6.90, \mathrm{p}>\right.$ .05]. Bu durum deneysel işlem öncesi farklı öğrenme stillerinde bulunan öğrencilerin 
matematiksel muhakeme becerisi açısından denk gruplar olduğunu ifade eder.

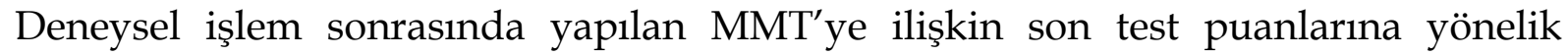
Kruskal Wallis testinde deneysel işlem sonrasında öğrenme stilleri grupları arasında anlamlı bir farklılaşmanın olmadığı görülmektedir $\left[\chi^{2} \quad(3,23)=4.97\right.$, $p>$.05]. Bu bulgular bu öğrenme ortamının öğrenme stilleri gruplarını ayrı ayrı matematiksel muhakeme becerisini geliştirmesine rağmen bu gelişimde öğrenme stilleri arasında anlamlı bir farklılaşma bulunmamıştır. Bunun öğrenme ortamında öğrenme stilleri yönünden öğrencilerin heterojen gruplarda öğrenme sürecini geçirmelerinden kaynaklandığı düşünülmektedir. Heterojen gruplar içinde farklı özelliklere sahip öğrencilerin birbirinin öğrenmelerine ve muhakemelerine etki ettikleri söylenebilir.

Zenginleştirilen öğrenme ortamının öğrencilerin problem çözmeye yönelik tutumlarını iyileştirmeye etkisinin olup olmadı̆̆ını belirlemek amacıyla MPÇTÖ (Öntest-Sontest)'ye ilişkin ilişkili örneklemler için t- testi yapılmış ve sonuçlar Tablo $4^{\prime}$ te gösterilmiştir.

Tablo 4

MPÇTÖ'ye İlişkin Öntest ve Sontest Ortalama Puanlarn t-Testi Sonuçlarn

\begin{tabular}{ccccccc}
\hline $\begin{array}{c}\text { Ölçüm } \\
\text { (MPÇTÖ) }\end{array}$ & $\mathrm{n}$ & $\overline{\mathrm{x}}$ & ss & sd & $\mathrm{t}$ & $p$ \\
\hline Öntest & 23 & 3.19 & .53 & & & \\
Sontest & 23 & 3.79 & .42 & 22 & -6.67 & .00 \\
\hline
\end{tabular}

Tablo 4 incelendiğinde öğrencilerin öğrenme ortamında gerçekleştirilen öğretim sonrasında matematik problemi çözmeye yönelik tutumlarında anlamlı bir artış olduğu söylenebilir $[\mathrm{t}(22)=6.67, p<.05]$. Öğrencilerin uygulama öncesi matematik problemi çözmeye yönelik tutum puanlarının ortalaması $\bar{X}=3.19$ iken, uygulama sonrasında $\overline{\mathrm{X}}=3.79$ ' a yükselmiştir. Bir başka değişle öğrencilerin öğretim öncesinde matematik problemi çözme tutum düzeyi kararsız düzeyindeyken öğretim sonrası olumlu düzeydedir. Bu bulgu, farklı öğrenme yöntemleriyle zenginleştirilen öğrenme ortamının, öğrencilerin matematik problemi çözmeye yönelik tutumu iyileştirmede önemli bir etkiye sahip olduğunu gösterir.

\section{Tartışma, Sonuç ve Öneriler}

$\mathrm{Bu}$ araştırmanın amacı, farklı öğrenme yolları kullanılarak zenginleştirilen öğrenme ortaminda öğrenme tercihlerine göre oluşturulan işbirlikli heterojen öğrenci gruplarıla gerçekleştirilecek öğretimin matematiksel muhakeme becerisine ve problem çözmeye yönelik tutuma etkisini incelemektir.

“Zenginleştirilmiş öğrenme ortamının öğrencilerin matematiksel muhakeme becerilerini geliştirmeye etkisi var midır?" şeklinde ifade edilen alt probleme cevap aramak için yapılan analizler sonucunda, öğrencilerin matematiksel muhakeme testine ilişkin son test puanlarının ön test puanlarına göre anlamlı düzeyde $(z=-4.19$, p<.05) daha yüksek olduğu tespit edilmiştir. MMT'deki soruların çözümünde muhakeme becerisinin kullanılması gerekliliği düşünüldüğünde, bu öğrenme 
ortaminin öğrencilerin muhakeme becerisini geliştirdiği söylenebilir. Öyle ki tüm öğrencilerin $\mathrm{MMT}^{\prime}$ den aldıkları puanlar incelendiğinde her öğrencide farklı oranlarda olsa da şaşırtıcı bir şekilde son test puan ortalamalarının ön test puan ortalamalarından daha yüksek olduğu görülmektedir. Ayrıca her öğrencinin MMT'ye öntest ve sontestte verdikleri cevaplar kıyaslandığında da muhakeme becerilerinin öğretim süreci sonunda daha iyi olduğu belirlenmiştir.

Bu çalışmada kullanılan farklı öğrenme yolları dikkate alındığında literatürde matematiksel muhakeme becerisinin geliştirilebileceği ifade edilen birçok farklı durumdan bahsedilmektedir. Örneğin; Francisco ve Maher (2005), matematiksel muhakeme becerisinin geliştirilmesi adına tasarlanacak ortamların öğrencilerin kendi matematiksel aktivitelerini içselleştirebilecekleri, karmaşık problemlerin kullanıldı ğı, işbirlikli öğrenme ortamı sağlayacak ve öğrencilerin fikirlerini rahatça ifade edebilecekleri şekilde olması gerektiğinden bahsetmektedirler. Ayrıca öğrenme ortamında öğrenciyi öğrenmenin merkezine alacak şekilde öğrenciyi aktif kılan öğrenme ortamlarının bu beceriyi geliştirebileceğinden bahsedilmektedir (Kutluca, 2013; Umay, 2003). Uluslararası reform çalışmalarında da teknolojinin öğretimle bütünleştirildiği öğrencinin dikkatini çekecek nitelikte ortamların muhakeme becerisini geliştirme adına önemli olacağı da vurgulanmaktadır (National Council of Teachers of Mathematics [NCTM], 1989). Matematiksel muhakemenin geliştirilmesi adına ideal öğrenme ortamının sosyal etkileşimlere ve yapıcı tartı̧malara fırsat yaratacak ve öğrencilerin matematiksel düşüncelerini rahatlıkla ifade edecek şekilde olması gerektiğinden bahsedilmektedir (Schliemann ve Carraher, 2002). Pham (2015) ise somut materyallerin öğrenme ortamlarında kullanılmasının öğrencilerin matematiksel fikirlerini öne sürmelerine, bunları tartışmalarına, muhakeme ve iletişim becerisini kullanmalarına olanak tanıyacağını vurgulamıştır. Benzer şekilde Yürekli ve Gökçek (2020), kavram haritalarının hem matematiksel kavramların öğretilmesinde hem de ölçme değerlendirmede kullanılmasının öğrencilerin matematiksel fikirlerini rahatlıkla ifade edebileceğini işaret etmektedir. Öte taraftan öğrenme ortamında öğrencilerin bu düşüncelerini ifade edebilmelerine, ortaya koydukları sonucun doğruluğunu ispatlamalarına ve yanlış veya doğru muhakemelerinin farkına varmalarına olanak sağlayacak "Neden böyle düşünüyorsun?", "Bu sonuca nasıl ulaştın?", "Neden doğru olduğunu düşünüyorsun?", "Başka nasıl bir yol izleyebiliriz?" gibi soruların yöneltilmesi matematiksel muhakeme becerisini geliştirme adına önemli görülmektedir (Erdem, 2015; Olsson, 2018; Pilten, 2008).

Bu çalışmada elde edilen bulgular literatürle değerlendirildiğinde birden fazla duyu organına ve öğrencilerin bireysel farklılıklarından biri olan öğrenme stillerine hitap edecek şekilde farklı öğretim yöntemleri kullanılarak zenginleştirilen öğrenme ortamının matematiksel muhakemeyi geliştirdiğini göstermektedir. Bu sonuç farklı öğretim yöntemlerinin kullanıldığı (Erdem, 2015; Erdem vd., 2019; Erdem ve Soylu, 2019) çalışmalarla uyumluluk göstermektedir. Ayrıca işbirlikli gruplar halinde öğrenmelerin yapıcı tartışmalarla desteklendiği (Doruk vd., 2018; Houssart ve Sams, 2008; McClain ve Coob, 2001; Mueller ve Yankelewitz, 2014 ), somut materyal kullanmanın (Gürbüz, 2006; Pham, 2015), teknolojinin öğretimle bütünleştirilmesinin sağlanması (Kramarski ve Zeichner, 2001; Olsson, 2018), öğretimde oyunların kullanılması (Lach ve Sakshaug, 2004), günlük yaşamla ilişkilendirilerek 
öğrenmelerin gerçekleştirilmesi (Fitriana vd., 2018) ve açık uçlu problemlerin öğrenme ortamında kullanılması (Erdem ve Gürbüz, 2015; Kasmer ve Kim, 2011; Muin, Hanifah ve Diwidian, 2018) matematiksel muhakemenin gelişiminde oldukça etkili olduğunu belirten çalışmalarla desteklenmektedir. Ayrıca bu çalışmada öğrencilerle yapılan zenginleştirilmiş öğrenme ortamında kullanılan problemlerin çözümlerinde öğrencileri farklı çözüm stratejisi kullanmaya teşvik edilmesi matematiksel muhakemenin gelişiminde etkili olduğu söylenebilir. Nitekim problem çözerken farklı çözüm stratejilerin kullanılmasının önemli olduğunu ve üst düzey düşünme becerilerine katkısı olduğu ifade edilmektedir (Kükey, Aslaner ve Tutak, 2019)

“Zenginleştirilmiş öğrenme ortamının öğrencilerin matematiksel muhakeme becerilerini geliştirmede öğrenme stilleri açısından anlamlı bir fark var mıdır?" şeklinde ifade edilen alt probleme cevap aramak için yapılan analizlerde, bu öğrenme ortamının öğrenme her dört öğrenme stilli grubundaki öğrencilerin ayrı ayrı anlamlı şekilde matematiksel muhakeme becerisini geliştirdiği belirlenmiştir $(p<.05)$. Ayrıca bu öğrenme stilleri gruplarında bulunan öğrencilerin deneysel işlem öncesi muhakeme becerileri açısından anlamlı bir farklılık olmadığ belirlenmiştir $\left[\chi^{2}(3,23)=6.90, p>.05\right]$. Bir başka deyişle deneysel işlem öncesi öğrenme stilleri gruplarının muhakeme becerisi açısından denk olduğu söylenebilir. Deneysel işlem sonrasında öğrenme stillerinin matematiksel muhakeme becerisi açısından anlamlı bir farklılaşma olmadı ğ belirlenmiştir $\left[\chi^{2}(3,23)=4.97, p>.05\right]$. $\mathrm{Bu}$ sonuçlar bu öğrenme ortamında öğrenme stilleri bağlaminda öğrencilerin matematiksel muhakeme becerisini geliştirdiğini ancak muhakeme becerilerinin gelişimi açısından öğrenme stilleri grupları arasında anlamlı bir farklılaşma olmadığı söylenebilir. Bu sonucun öğrenme ortamında öğrencilerin heterojen gruplarda öğrenim görmesinden dolayı birbirlerinin öğrenmelerini ve muhakeme becerilerini etkilemesinden kaynaklandığı düşünülmektedir. Nitekim birinci alt probleme yönelik tartışmada muhakeme becerisinin gelişimini etkileyen birçok durumdan bahsedilmişti.

“Zenginleştirilmiş öğrenme ortamının öğrencilerin problem çözmeye yönelik tutumlarını iyileştirmede anlamlı bir etkisi var mıdır?" şeklinde ifade edilen alt probleme cevap aramak için yapılan analizler sonucunda, bu öğrenme ortamında yapılan öğretimler sonrasında öğrencilere uygulanan MPÇTÖ son test puanlarının ön test puanlarına göre anlamlı bir düzeyde $[\mathrm{t}(22)=6.67, p<.05]$ daha yüksek olduğu tespit edilmiştir. Başka bir ifadeyle deneysel işlem öncesi öğrencilerin matematik problemi çözme tutum düzeyi kararsız düzeyindeyken $(\overline{\mathrm{X}}=3.19)$ deneysel işlem sonrası öğrencilerin tutum düzeyi olumlu düzeyine çıkmıştır $(\overline{\mathrm{X}}=3.79)$. Bu öğreneme ortamında farklı öğretim yöntemleriyle sürecin eğlenceli şekilde geçirildiği, araştırmacının bu süreçte bireysel farklılıklar dikkat ederek yaklaşımlar sergilediği, gruplar halinde problemler çözerek bu çözümler üzerinde tartışmalar yapılması ve farklı çözüm stratejilerine yönelik çalışmaların yapıldı̆̆ı göz önüne alındığında, bu öğrenme ortamının matematik problemi çözme tutumunu arttırdığ1 söylenebilir. Ayrıca sürecin birçok görsel uyaranla desteklenmesinden dolayı öğrenciler için ders cezbedici hale geldiği için tutumlarda olumlu yönde bir gelişme sergilendiği söylenebilir. 
Problem çözme matematik dersinin argümanlarından biri olarak düşünüldüğünde matematiğe olan tutum, matematik problemi çözme tutumu etkileyeceğini göz ardı edilmemesi gereklidir. Dolayısıyla matematiğe yönelik olumsuz tutumu veya ön yargıyı ortadan kaldırmak için öğrencilerin derse dikkatlerini çekecek, görsel materyallerle öğrenilenlerin akılda kalıcı kalmasını kolaylaştıran (Çetin ve Mirasyedioğlu, 2019) birçok duyu organına hitap edecek şekilde, öğrencilerin olumlu tutum geliştirmelerini sağlayan ortamların ve etkinliklerin düzenlenmesi son derece önemli olduğundan bahsedilmektedir (Şengül ve Dereli, 2013b). Literatürde bu tür önerileri göz önüne alınarak düzenlenen öğretimlerin matematiğe ve argümanı olan matematik problemi çözme tutumunu olumlu yönde etkilediği belirlenen çalışmalara rastlanmaktadır (Aksoy, 2010; Clements, 2000; Gelen ve Özer, 2010; McNeil ve Jarvin, 2007; Özgen ve Alkan, 2014; Şengül ve Dereli, 2013a). Bu öğrenme ortamında öğrencilerin öğrenme tercihlerini içerisinde barındırarak zenginleştirilen bu öğrenme ortamının problem çözme becerisini geliştirdiği ve bu sebeple öğrencilerin deneysel işlem öncesine göre daha olumlu tutumlar geliştirdiği söylenebilir. Nitekim öğrenme stillerine dayalı gerçekleştirilen öğrenme süreçlerinin öğrencilerde olumlu tutum yarattığ1 ve tutumu geliştirdiği yönünde sonuçlar elde eden çalışmalar bulunmaktadır (Dikkartın, 2006; Peker, 2003; Ursin, 1995; Wilkerson ve White, 1988). Louange (2007) öğrenme stillerinin problem çözme becerisini geliştirmede önemli bir etken olduğunu belirlemiştir. Benzer şekilde Özgen ve Alkan (2014) yapılandırmacı yaklaşımla öğrencilerin öğrenme stillerine yönelik etkinliklerin yapıldığında problem çözme becerilerini geliştirdiğini belirlemişlerdir. Ayrıca bu öğrenme ortamında konular günlük yaşamla ilişkilendirildiği için öğrencilerin tutumlarının geliştiği düşünülmektedir. Çünkü Özgen, Ay, Kılıç, Özsoy ve Alpay (2017) yaptıkları çalışmada günlük yaşamla ilişkilendirme ile problem çözme tutumu arasında pozitif bir ilişki olduğunu belirlemişlerdir. Benzer şekilde Özgen ve Pesen (2008) öğrenme ortamlarında günlük hayattan seçilen problemler ile bunlara bağlı etkinliklerin kullanılması matematik dersine olan ilgi ve isteği artıracağını ifade etmişlerdir. Bu araştırma sonuçlarından hareketle bazı öneriler geliştirilmiştir.

\section{Öğretmenlere yönelik öneriler:}

- Matematik dersleri işlerken matematiksel muhakeme becerisini göz ardi etmemeli ve çözümüne hemen ulaşılmayan açık uçlu problemlere yer vermelidir.

- Öğrenme ortamları öğrencilerin derslerde matematiksel fikirlerini rahatlıkla ifade edebilecekleri şekilde düzenlenmelidir.

-Öğrencilerin matematiksel muhakeme becerilerini kullanmasına fırsat sağlayacak şekilde ve anlamlı öğrenme sağlaması adına dersler neden sonuç ilişkisi içerisinde sorgulayıcı yaklaşımla işlenmelidir.

-Matematik derslerinde öğrencilerin öğrenme stilleri göz önüne alınarak zenginleştirilmiş öğrenme ortamları tasarlanmalıdır.

\section{Araştırmacılara yönelik öneriler:}

- Problem çözme sürecinde yapılan muhakeme hatalarının belirlenmesine ve bunların giderilmesine yönelik çalışmalar yapılabilir. 
- Bu çalışmada ele alınan konulardan farklı olarak matematik öğretim programinda belirtilen konulara yönelik zenginleştirilmiş öğrenme ortamının etkileri kontrol grubu dâhil edilerek araştırılabilir.

- Öğrencilerin öğrenme stilleri ve matematik odaklı epistemolojik inançları ile matematiksel muhakeme becerileri arasındaki ilişki araştırılabilir.

\section{Bilgilendirme}

Bu çalışma Dicle Üniversitesi Bilimsel Araştırma Projeleri (DUBAP) Koordinatörlüğünce ZGEF.19.005 nolu yüksek lisans projesi kapsamında desteklenmiştir. DUBAP koordinatörlüğüne teşekkürlerimizi sunarı.

\section{Kaynakça}

Aksoy, N. C. (2010). Oyun destekli matematik öğretimin ilköğretim 6.sını öğrencilerin kesirler konusundaki başarı, başarı güdüsü, öz -yeterlilik ve tutumlarını gelişimlerine etkisi (Yayınlanmamış yüksek lisans tezi). Gazi Üniversitesi Eğitim Bilimleri Enstitüsü, Ankara.

Ayal, C. S., Kusuma, Y. S., Sabandar, J., and Dahlan, J. A. (2016). The enhancement of mathematical reasoning ability of junior high school students by applying mind mapping strategy. Journal of Education and Practice, 7(25), 50-58. https:/ / files.eric.ed.gov/fulltext/EJ1115860.pdf

Bragg, L. A., Herbert, S., and Davidson, A. (2018). Identifying, promoting, and assessing reasoning focused on analysing. Australian Primary Mathematics Classroom, 23(2), 3-7. https://files.eric.ed.gov/fulltext/EJ1231248.pdf

Clements, D. H. (2000). 'Concrete' manipulatives, concrete ideas. Contemporary Issues in Early Childhood, 1(1), 45-60.

https:/ /journals.sagepub.com/doi/pdf/10.2304/ciec.2000.1.1.7

Çanakçı, O. (2008). Matematik problemi çözme tutum ölçeğinin geliştirilmesi ve değerlendirilmesi (Yayımlanmamış doktora tezi). Marmara Üniversitesi Eğitim Bilimleri Enstitüsü, İstanbul.

Çetin, Y., ve Mirasyedioğlu, Ş. (2019). Teknoloji destekli probleme dayalı öğretim uygulamalarının matematik başarısına etkisi. Journal of Computer and Education Research, 7 (13), 13-34. https:/ / doi.org/10.18009/jcer.494907

Danişman, Ş., and Erginer, E. (2017). The predictive power of fifth graders' learning styles on their mathematical reasoning and spatial ability. Cogent Education, 4(1), 1-18. http:/ / dx.doi.org/10.1080/2331186X.2016.1266830

Diezmann, C., and English, L. D. (2001). Developing young children's mathematical power. Roeper Review, 24(1), 11-13. https:/ / doi.org/10.1080/02783190109554118

Dikkartın, F. T. (2006). Geometri öğretiminde 4MAT öğretim modelinin öğrenci başarısı ve tutumları üzerine etkisi (Yayınlanmamış yüksek lisans tezi). Balıkesir Üniversitesi Fen Bilimleri Enstitüsü, Balıkesir.

Doruk, M., Duran, M., ve Kaplan, A. (2018). Argümantasyon tabanlı olasılık öğretiminin ortaokul öğrencilerinin matematiksel üstbiliş farkındalıklarına ve olasılıksal muhakeme becerilerine etkisinin incelenmesi. Necatibey Eğitim Fakültesi Elektronik Fen ve Matematik Eğitimi Dergisi, 12(1), 83-121. https:/ / doi.org/10.17522/balikesirnef.437714 
Erdem, E. (2015). Zenginleştirilmiş öğrenme ortamının matematiksel muhakeme ve tutuma etkisi (Yayınlanmamış doktora tezi). Atatürk Üniversitesi Eğitim Bilimleri Enstitüsü, Erzurum.

Erdem, E., and Gürbüz, R. (2015). An analysis of seventh-grade students' mathematical reasoning. Çukurova Üniversitesi Ĕ̆itim Fakültesi Dergisi, 44(1), 123-142. https:/ / dergipark.org.tr/tr/download/article-file/46542

Erdem, E., ve Soylu, Y. (2019). Farklı öğretim yolları kullanarak tasarlanan bir öğrenme ortamının matematiksel muhakemeye ve matematik tutumuna etkisi. Kastamonu Education Journal, 27(3), 1273-1290. https:/ / doi.org/10.24106/kefdergi.3056

Erdem, E., Firat, T., and Gürbüz, R. (2019). Improving mathematical reasoning and mathematics attitude of disadvantaged children in rural regions. Journal of Computer and Education Research, 7 (14), 673-697. https:/ / doi.org/10.18009/jcer.628742

Fischbein, E., and Schnarch, D. (1997). The evolution with age of probabilistic, intuitively based misconceptions. Journal for Research in Mathematics Education, 28(1), 96-105.

Fitriani, D., Rayid, Y., and Dewanti, R. (2020). Need analysis on developing essay teaching material base on brainwriting strategy. International e-Journal of Educational Studies (IEJES), 4 (7), 81-92. DOI: 10.31458/iejes.608018

Fitriana, E. M., Musdi, E., and Anhar, A. (2018). Development of learning design based on realistic mathematics education. International Conferences on Educational, Social Sciences and Technology (pp.699-706), February 14th-15th 2018, Padang, Indonesia. https:/ / doi.org/10.29210/20181103

Francisco, J. M., and Maher, C. A. (2005). Conditions for promoting reasoning in problem solving: Insights from a longitudinal study. Journal of Mathematical Behavior, 24, 361-372. https:// doi.org/10.1016/j.jmathb.2005.09.001

Gelen, İ., ve Özer, B. (2010). Oyunlaştırmanın beşinci sınıf matematik dersinde problem çözme becerisi ve derse karşı tutum üzerindeki etkisi. e-Journal of New World Sciences Academy, 5(1), 71-87.

Gencel, İ. E. (2007). Kolb’un deneyimsel öğrenme kuramına dayalı öğrenme stilleri envanteri-III' ü Türkçeye uyarlama çalışması. Dokuz Eylül Üniversitesi Sosyal Bilimler Enstitüsü Dergisi, 9(2), 120-139.

Gürbüz, R. (2006). Olasılık kavramlarıyla ilgili geliştirilen öğretim materyallerinin öğrencilerin kavramsal gelişimine etkisi. Dokuz Eylül Üniversitesi Buca Eğitim Fakültesi Dergisi, 20, 59-68. https:/ / dergipark.org.tr/ en/download/articlefile/235069

Houssart, J., and Sams, C. (2008). Developing mathematical reasoning through games of strategy played against the computer. The International Journal for Technology in Mathematics Education, 15(2), 59-71.

Kasmer, L., and Kim, O. K. (2011). Using prediction to promote mathematical understanding and reasoning. School Science and Mathematics, 111(1), 20-33. https:/ / doi.org/10.1111/j.1949-8594.2010.00056.x

Kilpatrick, J., Swafford, J., and Findell, B. (Eds.). (2001). Adding it up: Helping children learn mathematics. Washington, DC: National Academy Press.

Kolb, D. A. (2005). Learning style inventory-version 3.1. Hay Group. 
Kramarski, B., and Zeichner, O. (2001). Using technology to enhance mathematical reasoning: Effects of feedback and self-regulation learning. Educational Media International, 38(2-3), 77-82. https:// doi.org/10.1080/09523980110041458

Kramarski, B., Mevarech, Z. R., and Lieberman A. (2001). Effects of multilevel versus unilevel metacognitive training on mathematical reasoning. Journal of Educational Research, 94(5), 292-300. https:/ / doi.org/10.1080/00220670109598765

Kutluca, T. (2013). Yapılandırmacı öğrenme-öğretme yaklaşımı. In G. Ekici ve M. Güven (Eds.), Yeni öğrenme-öğretme yaklaşımları ve uygulama örnekleri (ss. 620-653). Ankara: Pegem Akademi

Kükey, E., Aslaner, R., ve Tutak, T. (2019). Matematiksel düşünmenin varsayımda bulunma bileşeni kapsamında ortaokul öğrencilerinin kullandıkları problem çözme stratejilerinin incelenmesi. Journal of Computer and Education Research, 7 (13), 146-170. https:/ / doi.org/10.18009/jcer.535610

Lach, T., and Sakshaug, L. (2004). The role of playing games in developing algebraic reasoning, spatial sense and problem solving. Focus on Learning Problems in Mathematics, 26(1), 34-42.

Lithner, J. (2008). A research framework for creative and imitative reasoning. Educational Studies in Mathematics, 67, 255-276. https:/ / doi.org/10.1007/s10649007-9104-2

Louange, J. E. G. (2007). An examination of the relationships between teaching and learning styles, and the number sense and problem solving of year 7 students (Unpublished doctoral dissertation). Edith Cowan University, Perth Western, Australia.

McClain, K., and Cobb, P. (2001). An analysis of development of sociomathematical norms in one first-grade classroom. Journal for Research in Mathematics Education, 32(3), 236-266. doi:10.2307/749827

McNeil, N. M., and Jarvin, L. (2007). When theories don't add up: Disentangling the manipulatives debate. Theory into Practice, 46(4), 309-316. https://doi.org/10.1080/00405840701593899

Miles, M. B., and Huberman, A. M. (1994). An expanded sourcebook: qualitative data analysis (2nd Editon). Thousand Oaks, CA: Sage.

Milli Eğitim Bakanlığı [MEB]. (2015). Ortaokul matematik dersi (5,6,7 ve 8. stmıflar) öğretim programı. Ankara: Talim ve Terbiye Kurulu Başkanlığ1.

Milli Eğitim Bakanlığı [MEB]. (2018). Matematik dersi öğretim programı (İlkokul ve ortaokul 1, 2, 3, 4, 5, 6, 7 ve 8. Sinıflar). Ankara: Talim ve Terbiye Kurulu Başkanlı̆̆1.

Mueller, M., and Yankelewitz, D. (2014). Fallacious argumentation in student reasoning: Are there benefits? European Journal of Science and Mathematics Education, 2(1), 27-38. http:/ / scimath.net/articles/21/213.pdf

Muin, A., Hanifah, S. H., and Diwidian, F. (2018, January). The effect of creative problem solving on students' mathematical adaptive reasoning. In Journal of Physics: Conference Series (Vol. 948, No. 1, p. 012001). IOP Publishing. http:/ / iopscience.iop.org/article/10.1088/1742-6596/948/1/012001/pdf adresinden 12/12/2018 tarihinde indirilmiştir.

National Council of Teachers of Mathematics [NCTM]. (1989). Curriculum and evaluation standards for school mathematics. Reston: Virginia. 
Novak, J. D., and Gowin, D. B. (1984). Learning how to learn. New York: Cambridge University.

Olsson, J. (2018). The contribution of reasoning to the utilization of feedback from software when solving mathematical problems. International Journal of Science and Mathematics Education, 16(4), 715-735.

https:/ /link.springer.com/article/10.1007/s10763-016-9795-x

Özalp, I. (2006). Karikatür tekniğinin fen ve çevre eğitimde kullanılabilirliği üzerine bir araştırma (Yayınlanmamış yüksek lisans tezi). Celal Bayar Üniversitesi Fen Bilimleri Enstitüsü, Manisa.

Özgen, K., ve Alkan, H. (2014). Yapılandırmacı öğrenme yaklaşımı kapsamında, öğrencilerin öğrenme stillerine uygun öğrenme etkinliklerinin akademik başarı ve tutuma etkileri: fonksiyon ve türev kavramı örneklemesi. Turkish Journal of Computer and Mathematics Education, 5(1), 1-38. https:/ / doi.org/10.16949/turcomat.35299

Özgen, K., ve Pesen, C. (2008). Probleme dayalı öğrenme yaklaşımı ve öğrencilerin matematiğe yönelik tutumları. Dicle Üniversitesi Ziya Gökalp Eğitim Fakültesi Dergisi, 11, 69-83. https:/ / dergipark.org.tr/en/download/article-file/787163

Özgen, K., Ay, M., Kılıç, Z., Özsoy, G., ve Alpay, F. N. (2017). Ortaokul öğrencilerinin öğrenme stilleri ve matematiksel problem çözmeye yönelik tutumlarının incelenmesi. Mehmet Akif Ersoy Üniversitesi Eğitim Fakültesi Dergisi, 1(41),215244. https:// doi.org/10.21764/efd.55023

Peker, M. (2003). Öğrenme stilleri ve 4MAT yönteminin öğrencilerin matematik tutum ve başarılarına etkisi (Yayımlanmamış doktora tezi). Gazi Üniversitesi Eğitim Bilimleri Enstitüsü, Ankara.

Pellerin, J. (2012). Improving mathematical reasoning and discourse through problem solving. University of South Florida St. Petersburg Student Research Journal,2(1),114.

Pham, S. (2015). Teachers' perceptions on the use of math manipulatives in elementary classroom (Unpublished master's thesis). University of Toronto. 02/12/2018 Tarihinde https://tspace.library.utoronto.ca/bitstream/1807/68723/1/Pham_Son_H_201 506_MT_MTRP.pdf adresinden indirilmiştir.

Pilten, P. (2008). Üst biliş stratejileri öğretiminin ilköğretim beşinci sınıf öğrencilerinin matematiksel muhakeme becerilerine etkisi (Yayınlanmamış doktora tezi). Gazi Üniversitesi Eğitim Bilimleri Enstitüsü, Ankara.

Polaki, M. V. (2002). Using instruction to identify key features of Basotho elementary students' growth in probabilistic thinking. Mathematical Thinking and Learning, 4(4), 285-313. https://doi.org/10.1207/S15327833MTL0404_01

Schliemann, A. D., and Carraher, D. W. (2002). The evolution of mathematical reasoning: Everyday versus idealized understandings. Developmental Review, 22(2), 242-266. https://doi.org/10.1006/drev.2002.0547

Şengül, S., ve Dereli, M. (2013a). Tam sayılar konusunun karikatürle öğretiminin 7. sinıf öğrencilerinin matematik tutumuna etkisi. Educational Sciences: Theory and Practice, 13(4), 1-26. Doi: 10.12738/estp.2013.4.1486

Şengül, S., ve Dereli, M. (2013b). Karikatürle öğretimin 7. sınıf öğrencilerinin tam sayılar konusundaki başarılarına ve kalıcılık düzeylerine etkisi. The Journal of 
Academic Social Science Studies, 6(7), 973-1003.

http:/ / dx.doi.org/10.9761/JASSS1610

Umay, A. (2003). Matematiksel muhakeme yeteneği. Hacettepe Üniversitesi Ĕ̆itim

Fakültesi Dergisi, 24, 234-243. https://dergipark.org.tr/en/download/articlefile/87843

Ursin, V. D. (1995). Effects of the 4MAT system of instruction on achievement, products, and attitudes toward science of ninth-grade students (Unpublished doctoral dissertation). The University of Connecticut, Connecticut, USA.

Wilkerson, R.M., and White, K.P. (1988). Effects of the 4MAT system of the instruction on students' achievement, retention and attitudes. The Elementary School Journal, 88(4), 357-368.

Yürekli, A., ve Gökçek, T. (2020). Ortaokul 5.sınıf açılar konusunun öğretiminin kavram haritası ile değerlendirilmesi. Cumhuriyet International Journal of Education, 9(1), 88-107. http:/ / dx.doi.org/10.30703/cije.541106

\section{Summary}

\section{Introduction}

One of the main goals of mathematics is to provide individuals with basic math skills, problem solving and mathematical thinking skills to overcome the problems they will encounter in their daily lives. The role that thinking plays a role in keeping mathematics together should be the goal to develop students' mathematical reasoning skills and encourage their use in any math class.

It is important to diversify the learning environment and address many sensory organs and focus the student on learning activities to achieve effective learning. In this context, "entertaining educational games", "computer-based teaching practices", "concept cartoons", "concrete materials", "association with daily life" and "collaborative discussion groups" and "high level open questions" with different learning styles. It is believed that mathematical concepts can be learned more effectively and that mathematical reasoning skills are developed using a learning environment. On the other hand, there is an idea that attitudes towards problem solving will develop positively thanks to various and fun methods. It is thought that the studies to be developed for students to develop positive attitudes towards solving mathematical problems reflect the use of students' mathematical reasoning skills positively. Therefore, examining the effect of enriched learning environments on mathematical thinking and problem solving in the context of learning styles is considered important and necessary to understand the literature and curriculum that the classroom is based on and the teacher to teach to contribute. The purpose of this study is to examine the effects of teaching on mathematical reasoning skills and problem solving attitudes with collaborative heterogeneous groups of students created according to learning preferences enriched by the use of different learning paths.

\section{Method}

The randomly selected participants are aimed at 23 students in public secondary school in terms of mathematics and heterogeneous distribution and learning styles. 
The study was carried out at a school located in the city center in Southeastern Anatolia. Teaching fractions and integers in enriched learning environments; Technology-supported applications, educational games, concrete materials and cartoons were carried out in 6 weeks ( 26 hours in total) by associating them with constructive discussions with daily life and common heterogeneous groups. The research was carried out by using an experimental design that is not a pretestposttest control group, which is one of the quantitative research approaches. In the study, the learning preferences of the students were determined by using the "Learning Styles Scale (PSS)". The study data were obtained from the answers given to the Mathematical Reasoning Test (MRT) and Mathematics Problem Solving Attitude Scale (MPSAS) in the pre-test and post-test. Responses to MRT were analyzed using the "Wilcoxon Signed Rank Test" and the Kruskal Wallis Test. In addition, some student answers related to MRT after pretest and posttest were compared. Responses to MPCAS were used for t-test on relevant samples.

\section{Results}

In the learning environment developed in this study, teaching has been shown to significantly improve students' mathematical reasoning skills and significantly improve their attitudes towards solving math problems. It has also been found that this learning environment has significantly improved mathematical reasoning skills for each learning style, but there is no difference in developing a controversial skill related to learning styles.

\section{Discussion}

Given the need to use reasoning skills while solving questions in MRT, it can be said that this learning environment improves students' reasoning skills. When examining the results of all MRT students, it was found that although each student had different rates, the averages after the test were higher than the averages before the test. By comparing the answers of each student in the pretest and posttest with MRT, they found that their thinking skills were better at the end of the teaching period. Considering the different learning paths used in this study, many different situations in which mathematical reasoning skills can be developed are mentioned in the literature. For example, Francisco and Maher (2005) stated that in the development of mathematical reasoning skills, environments should be designed to internalize students 'own mathematical activities, use complex problems, provide a cooperative learning environment and relax students' ideas. They also mentioned that learning environments that allow the student to be active in a learning environment can improve this ability (Umay, 2003). International reform studies emphasize that environments where technology is integrated into the classroom are important for developing student's reasoning skills (NCTM, 1989). It should be noted that in order to develop mathematical thinking, the ideal learning environment will create opportunities for social interactions and constructive discussions, and that students' mathematical thoughts can be expressed (Schliemann and Carraher, 2002). Pham (2015) emphasized that the use of concrete materials in learning environments will enable students to present, discuss and practice their mathematical ideas. On the other hand, students can express their thoughts in the learning environment, prove the correctness of their results, and recognize their misconceptions: "Why do you 
think so?", "How did you get this result?", "Why do you think? Is it true?", "How else? It is important to ask questions such as "can we follow a path" in mathematical reasoning skills (Erdem, 2015; Olsson, 2018; Pilten, 2008). When the findings obtained in this study are reviewed via literature it indicates that the learning environment enriched by the use of different teaching methods which addresses to more than one receptor and learning styles which are one of the students' individual differences improves mathematical reasoning.

The study showed that students developed mathematical reasoning skills in four learning style groups, but there was no significant difference in how these skills developed. It is believed that this result depends on the fact that students learn heterogeneous groups and mutually influence their learning and reasoning skills. As mentioned earlier, there are many situations that affect the judiciary.

Since the process is fun with different teaching methods in this learning environment, the researcher showed approaches in this process by paying attention to individual differences, discussing these solutions, solving problems in groups and working in line with different solution strategies. This learning environment increases the attitude towards solving mathematical problems. In fact, it is stated that it is very important to organize environments and activities that attract students' attention to the classroom and make it easier to keep what they learn permanently with visual materials, so that students can develop a positive attitude for negative attitude. In addition, it eliminated prejudices against mathematics (Şengül and Dereli, 2013b). It can be said that this learning environment, enriched by the inclusion of the learning preferences of the students in this learning environment, improves the problem solving ability and therefore the students develop more positive attitudes than the experimental process. Indeed, there are studies in the literature that produce positive attitudes and obtain learning outcomes based on learning styles that improve student attitudes (Dikkartın, 2006; Özgen and Alkan, 2014; Peker, 2003; Ursin, 1995; Wilkerson and Beyaz, 1988).

\section{Pedagogical Implications}

This study shows that teachers should not ignore their mathematical reasoning skills during mathematics lessons and clearly contain problems that cannot be solved. Learning environments should be designed so that students can express their mathematical ideas in the classroom and use their mathematical reasoning skills. Lessons should be taught in a cause-effect relationship to enable meaningful learning. In mathematics lessons, enriched learning environments should be designed by considering the learning styles of students. Studies can be conducted to identify and eliminate argumentation errors in the problem solving process. Contrary to the topics discussed in this study, the effects of the enriched learning environment on the subjects specified in the mathematics curriculum can be examined with the participation of the control group. The relationship between student learning styles and mathematically oriented epistemological beliefs and mathematical reasoning skills can be investigated.

\section{Authors' Biodata/ Yazar Bilgileri}

Tamer KUTLUCA Dicle Üniversitesi Ziya Gökalp Eğitim Fakültesi Matematik ve Fen Bilimleri Eğitimi Bölümü Matematik Eğitimi Anabilim dalında Doç. Dr. olarak 
görev yapmaktadır. Ulusal ve Uluslararası hakemli dergilerde editörlük görevi bulunmaktadır.

Tamer Kutluca works as an Associate Professor Doctor in the Departments of Mathematics and Science Education at Dicle University, Ziya Gokalp Faculty of Education. He is the editor of national and international refereed journals.

Ali TUM Adıyaman ilinde Milli Eğitim Bakanlığına bağlı bir ortaokulda matematik öğretmeni olarak görev yapmaktadır. Yüksek Lisans eğitimini Dicle Üniversitesi Eğitim Bilimleri Enstitüsü Matematik Eğitimi Bilim Dalı' nda tamamlamıştır.

Ali Tum works as a mathematics teacher in a middle school affiliated to the Ministry of National Education in Adiyaman. He completed his Graduate Education in the Departments of Mathematics Education at Dicle University, Institute of Educational Sciences. 